$\frac{78}{3-20}-80$

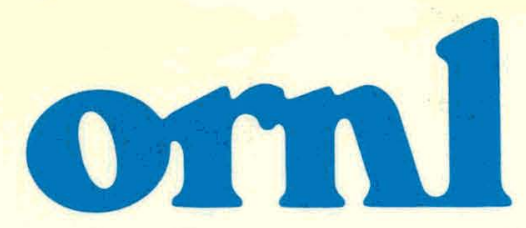

OAK

RIDGE

NATIONAL

LABORATORY

UNION

CARBIDE

\section{The Decentralized Solar Energy Technology Assessment Program: Review of Activities (April 1978-December 1979)}

\author{
Benson $\mathrm{H}$. Bronfman \\ Sam A. Carnes \\ Martin Schweitzer \\ Elizabeth Peelle \\ Gordon Enk
}




\section{DISCLAIMER}

This report was prepared as an account of work sponsored by an agency of the United States Government. Neither the United States Government nor any agency Thereof, nor any of their employees, makes any warranty, express or implied, or assumes any legal liability or responsibility for the accuracy, completeness, or usefulness of any information, apparatus, product, or process disclosed, or represents that its use would not infringe privately owned rights. Reference herein to any specific commercial product, process, or service by trade name, trademark, manufacturer, or otherwise does not necessarily constitute or imply its endorsement, recommendation, or favoring by the United States Government or any agency thereof. The views and opinions of authors expressed herein do not necessarily state or reflect those of the United States Government or any agency thereof. 


\section{DISCLAIMER}

Portions of this document may be illegible in electronic image products. Images are produced from the best available original document. 


\section{Printed in the United States of America. Available from National Technical Information Service U.S. Department of Commerce 5285 Port Royal Road, Springfield, Virginia 22161 NTIS price codes-Printed Copy: A06 Microfiche A01}

This report was prepared as an account of work sponsored by an agency of the United States Government. Neither the United States Government nor any agency thereof, nor any of their employees, makes any warranty, express or implied, or assumes any legal liability or responsibility for the accuracy, completeness, or usofulnese of any information, apparatus, product, or process disclosed, or represents that its use would not infringe privately owned rights. Heterence nerein to any specific commercial product, process, or service by trade name, trademark, manufacturer, or otherwise, does not necessarily constitute or imply its endorsement, recommendation, or favoring by the United States Government or any agency thereof. The views and opinions of authors expressed herein do not nccessarily state or reflect those of the United States Government or any agency thereof. 
ORNL/TM-7189

Contract No. W-7405-eng-26

THE DECENTRALIZED SOLAR ENERGY TECHNOLOGY ASSESSMENT PROGRAM: REVIEW OF ACTIVITIES (APRIL 1978 - DECEMBER 1979)

\author{
Benson H. Bronfman \\ Sam A. Carnes \\ Martin Schweitzer \\ Elizabeth Peelle \\ Energy Division/Oak Ridge National Laboratory \\ Gordon Enk \\ Institute on Man and Science
}

Prepared for..

Office of Solar Energy

Department of Energy

Date. Published: May 1980

NOTICE This document contains information of a preliminary nature.

It is subject to revision or correction and therefore does not represent a tinal report.

OAK RIDGE NATIONAL LABORATORY

Oak Ridge, Tennessee 37830

operated by

UNION CARBIDE CORPORATION

for the

DEPARTMENT OF ENERGY 


\section{THIS PAGE}

\section{WAS INTENTIONALLY \\ LEFT BLANK}




\section{CONTENTS}

Page

LIST OF TABLES

v

ABSTRACT

vii

LIST OF REPORTS

ix

1.0 INTRODUCTION AND OVERVIEW

1.1 Introduction

1.2 Overview

1.3 Organization of Report

1.4 Results

1.5 Conclusion

2.0 THE SOUTHERN TIER CENTRAL (New York) T.A. 13

2.1 Purpose of the STC Solar Technology Assessment 13

2.2 Project Participants 14

2.3 Project Organization 15

2.4 Findings

3.0 RICHMOND, KENTUCKY, T.A. 27

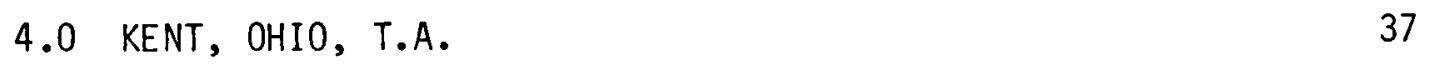

5.0 FRANKLIN COUNTY, MASSACHUSETTS, T.A. 43

6.0 REVIEW OF SOLAR LEGAL AND INSTITUTIONAL ISSUES 49

6.1 The Major Issues 49

6.2 The Major Actors 52

6.3 Implementation Options for Governments Seeking
to Further Solar Commercialization

7.0 SOCIAL CONSIDERATIONS RELATIVE TO DECENTRALIZED
SOLAR TECHNOLOGIES

8.0 PROGRAM REVIEW TEAM 73

8.1 First Meeting - December 6-8, 1978
Rensselaerville, N.Y.

8.2 Second Meeting - March 1-3, 1979
Washington, D.C.

8.3 Third Meeting - July 17-20, 1979
Rensselaerville, N.Y.

8.4 Fourth Meeting - November 7-9, 1979
Rensselaerville, N.Y.

9.0 GENERAL MANAGEMENT 89 
THIS PAGE

\section{WAS INTENTIONALLY LEFT BLANK}


LIST OF TABLES

Table

Page

1 Overall Organization of the Decentralized Solar Energy Technology Assessment Program (TAP)

2 Background and Support Studies for TAP at other institutions 


\section{THIS PAGE}

\section{WAS INTENTIONALLY LEFT BLANK}


vij

ABSTRACT

The Decentralized Solar Energy Technology Assessment Program (TAP), sponsored by the Office of Solar Energy, Department of Energy, is a technology assessment and planning activity directed at local communities. Specifically, the objectives of the TAP are:

- to assess the socioeconomic and institutional impacts of the widespread use of renewable energy technologies

- to involve communities in planning for their energy futures, and

- to plan for local energy development

This report discusses two major efforts of the TAP during the period Aprit 1978 - December 1979: the community TA's and several support studies.

Four communities have been contracted to undertake an assessmentplanning exercise to examine the role of solar renewable energy technologies in their future. The communities selected are the Southern Tier Central Region of New York State, (STC); Richmond, Kentucky; Kent, Ohio; and Frank in County, Massachusetts. Descriptions and progress to date of the community TA's are presented in detail.

Two major support study efforts are also presented. A review of existing literature on the legal and institutional issues relative to the adoption of decentralized solar technologies is summarized. A preliminary analysis of potential socioeconomic impacts and other social considerations relative to decentralized solar technologies is also described.

Several interesting preliminary findings have emerged from the TAP:

- The TA assessment-planning process can produce reasonable energy plans

- The TA assessment-planning process can function in a wide range of institutional settings

- The TA assessment-planning process can identiry important policy questions

- The TA assessment-planning process can provide a mechanism for the discussion of community values and goals

- The TA assessment-planning process has mobilized a wide range of local expertise

- The TA assessment-Dlannina process can serve an education.. function

- The TA communities are anxious to implement local energy plans which rely heavily on conservation, solar and other renewable eneryy technologies 


\section{THIS PAGE}

\section{WAS INTENTIONALLY \\ LEFT BLANK}




\section{REPORTS AVAILABLE FROM THE \\ DECENTRALIZED SOLAR ENERGY TECHNOLOGY \\ ASSESSMENT PROGRAM*}

Rashid Ahmad, Community-Based Technology Assessment: A Meta-Model, Battelle Columbus Laboratories, Washington Operations, Washington, D.C., July 1979 (draft).

L. M. Blair, J. Craven, and W. Stevenson, Community Level and Inicome Impacts of Biomass Energy Development and Use: A Pilot Case Study, Manpower Research Programs, Oak Ridge Associated Universities, Oak Ridge, Tennessee, October 1979 (working paper).

Benson H. Bronfman, Martin Schweitzer, Sam A. Carnes, Elizabeth Peelle, Garland Samue1s, Jr., and Thomas J. Wilbanks, Decentralized Solar Energy Technology Assessment Program: Research Plan, ORNL/TM-6913, Oak Ridge National Laboratory, Oak Ridge, Tennessee, May 1979.

T. Owen Carroll and Robert Nathans, Solar in Suburbia: A Case Study on Long Island, November, 1979 (draft).

Future Studies Program, Franklin County Energy Study: A Renewable Energy Future, University of Massachusetts, Amherst, Massachusetts, August 1979.

William F. Hornick and Gordon A. Enk, Value Issues in Technology Assessment, The Institute on Man and Science, Rensselaerville, New York, November 1979.

Kent Solar Project, Energy for Tomorrow: PZanning Kent's Energy Future, Kent, Ohio, March 1980.

A. Okagaki and J. Benson, County Energy PLanning Handbook, Center for Ecological Policies, Fairfax, Virginia, 1979.

Elizabeth Peelle, Social Considerations Relative to Decentralized Solar Technologies, Oak Ridge National Laboratory, Oak Ridge, Tennessee, March 1980 (draft).

Richmond Solar Project, Solar Options: Local Assessment by Richmond, Eastern Kentucky University, September 1979 (draft).

Martin Schweitzer, Review of Solar Legal and Institutional Issues in the Use of Decentralized Solar Energy Systems, ORNL/TM-7078, Oak Ridge National Laboratory, Oak Ridge, Tennessee, April 1980. 
Southern Tier Central Regional Planning and Development Board (New York), Renewable Energy Resource and Technology Assessment, ORNL/SUB-7549-1, National Technical Information Service, Springfield, Virginia, December 1978. (This volume includes three separate documents: Renewable Energy Resource Inventory, Renewable Energy Technology Handbook, and Technology Assessment Workbook).

Southern Tier Central Regional Planning and Development Board (New York), Energy Conservation and Development Plon, July 1979. Available from Southern Tier Central Regional Planning and Uevelopment Board, 53 1/2 Bridge Street, Curnily, NY 14830.

James Sullivan, Ron Corman, and David Morris, Baltimore: Solar and

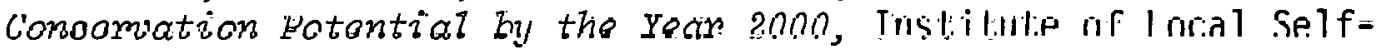
Reliance, Washington, D.C., October 1979 (draft).

*Requests for these reports should be directed to the original author or agency. 


\subsection{INTRODUCTION AND OVERVIEW}

\subsection{Introduction}

The Decentralized Solar Energy Technology Assessment Program (TAP) is directed at local energy planning. The program utilizes the concept of community-based technology assessment as a tool to analyze local energy capabilities, set community goals, examine local preferences and establish energy management and development goals and policies. The focus of the program is primarily on renewable energy technologies and conservation.

Any description of the TAP must be placed in the appropriate national energy context. The Domestic Policy Review (DPR) ${ }^{1}$ established goals for the contribution of solar and renewable energy to the national energy picture for the year 2000. Implementation of the goals established in the DPR have received support from the Executive and Legislative Branches, in the form of proposed policies and legislation directed at funding more local energy development and self-sufficiency. The Energy Management Partnership Act (EMPA) and Community. Energy Act, ${ }^{2}$ for example, propose to make funding available to states, communities and other areas to address inadequacies in investments in renewable energy programs, to ensure coordination of energy programs at all levels of government and involve direct citizen participation.

Involving local communities in the planning and implementation of renewable and inexhaustible energy planning and development is important for several reasons. First, local governments have the necessary tools to implement local plans, in the form of zoning 
ordinances, building codes, etc. Additionally, the small scale of solar and other renewable resources and their dependence upon local resources and conditions do not lend themselves readily to centralized decision-making. Local communities, then, can contribute very effectively to national goals of energy production and increased energy efficiency.

While there exist many examples of "active" communities and model projects, few examples of comprehensive assessment and planning programs exist. There are even fewer systematic analyses and assessments of the effectiveness of such programs, although some examples of information gathering and dissemination can be identified (e.g. Center for Renewable Resources, President's Clearinghouse for Community Energy Efficiency, National Association of County Officials, Solar Energy Research Institute).

The Decentralized Solar Energy Technology Assessment Program (TAP) represents one of three systematic programs for local renewable and inexhaustible energy planning established by the Department of Energy. The TAP is sponsored by the Office of Solar Energy and is managed by Oak Ridge National Laboratory (ORNL). Also managed by ORNL is the Local and Municipal Renewable Energy Planning Pilot Program, an activity sponsored by DOE's Office of Solar Policy. The third program, the Comprehensive Community Energy Management Program (CCEMP), is an activity of DOE's Office of Buildings and Community systems and is managed by Argonne National Laboratory.

\subsection{Overview}

While it is not the purpose of this report to provide a detailed comparison of other programs or projects with the TAP, the purposes and 
objectives of the TAP suggest several unique features. The objectives of the TAP are:

(1) to assess the social, economic, political, institutional and lifestyle impacts of the use of decentralized solar and renewable energy technologies.

(2) to involve communities in assessing and planning their own energy futures, in setting the planning agenda, as well as in selecting among options.

(3) to plan for energy development in the context of preferred al ternative futures.

The TAP is an application of a "new paradigm" of technology assessment, as described by Ahmad and Christakis. ${ }^{3}$ Conventional views of technology assessment assume the development of a technology and then ask how can the technology be applied, and once applied how will the technology impact society. Analyses of this view tend to be directed primarily at cost/benefit assessments and mitigation strategies. The "new paradigm" starts with the assumption of preferred alternative states of society and asks the question: Is the technology compatible with the preferred alternative state or alternative future? While it is still useful to ask "What does it mean?" to apply a technology (especially in the context of "unanticipated" adverse impacts), the "new paradigm" assumes that community values and goals are the driving forces and that alternative technologies are selected to fit in the community's future. Finally, the "new paradigm" carries with it an implicit commitment to social policy development so that the preferred future state of the community can be realized. 
It is in the context of the "new paradigm" that the TAP has been developed. This report summarizes the first phase of the TAP which represents a 21-month period from Apri1, 1978, through December, 1979. Table 1 shows the overall design for the TAP, which is composed of three types of efforts: Background studies, community TA's, and support studies.

The background studies consist of three scenarios and an energy primer, all of which were designed to provide communities with a set of prototypical scenarios and planning documents for utilization in the community TA phase. The support studies were designed to address specific needs of communities (e.g. Legal and Institutional Issues̀) or examine the wider, societal implications of the program (e.g. Decentralization Workshop). As shown in Table 2 all of the background studies and two of the support studies were undertaken by contractors other than ORNL. These studiès hàve been summarized elsewhere 5 , and will not be further described in this report.

\subsection{Organization of Report}

This report will summarize ORNL's major efforts in the TAP. Current efforts can be grouped into two components: the community TA's and three support efforts. The report is organized along these lines, first discussing the four community $T A$ 's and second reporting on the support study efforts.

The community TA's are the central focus of the TAP and the most direct application of the "new paradigm". Four community projects have been contracted and will be described in detail. The four communities 
Table 1. Overall Organization of the Decentralized Solar Energy Technology Assessment Program (TAP)

BACKGROUND

STUDIES

Baltimore

Brookraven

Franklin Co., Massachusetts

Planning Handbook

\section{COMMUNITY TA'S}

Southern Tier Central Region, New York

Richmond, Kentucky

Kent, Ohio

Franklin County, Massachusetts
SUPPORT STUDIES

Legal and Institutiona! Barriers

Social Costs and Issues

Review Team

Values in Technology Assessment

Decentralization Workshop 
Table 2. Background and SuFport Studies for TAP at other institutions

Activity

Rural scenario

Urban scenario

Suburban scenario

Energy Design

Primer

Values in Technolcgy

Assessment

\section{Decentralization}

Workshap

\author{
Irstitition \\ Univ. of Massachusetts \\ Institute for Local \\ Self-Reliance \\ SUNY Stony Brook \\ AIA Reseärch \\ Corporation \\ Institute on Man and \\ Science \\ Institute on Man and \\ Science
}

Principal Investigator

David Pomerantz

David Morris

Dr. Robert Nathans

Karen Hobson

a
Dr. Gordon Enk

Dr. Gorcion Enk 
are: the Southern Tier Central Region of New York State (STC), composed of Schuyler, Steuben and Chemung Countias; Richmond, Kentucky; Kent, Ohio; and Franklin County, Massachusetts. The four projects share the following components:

(1) Formation of a TA task team of community representatives to manage the project

(2) Development of a baseline community energy use profile

(3) Development of alternative energy scenarios and al ternative community futures

(4) Community education and communication

(5) Community assessment of the social, economic, institutional and lifestyle impacts of alternative scenarios

(6) Implementation strategies and plans

(7) Documentation.

The support studies play an important role in the coordination and integration of the TAP and have been designed to be responsive to community needs as well as to examine the wider implications of the program. For the reporting period, three efforts were undertaken by ORNL:

(1) A review of existing literature on legal and institutional issues relative to the adoption of decentralized solar technologies;

(2) A preliminary analysis of potential socioeconomic impacts and other social considerations relative to decentralized solar technologies; 
(3) The formation of a Program Review Team (PRT) to provide independent peer-review and oversight function for the project manager, principal investigator and DOE management.

One additional effort will be briefly discussed under the general category of support: the provision of management, coordination and other support for the TAP effort.

\subsection{Results}

While it is stili too early to undertake a full assessment of the TAP, several important preliminary findings have emerged.

- It is becoming apparent that the TA process, which is nonprescriptive and selectively technical (at the community's request) can produce reasonable local energy plans.

- The TA process can function in a wide range of institutional settings from a city planning office (Kent, Ohio) to an appropriate technology corporation (Franklin County, Massachusetts).

- The TA process can identify important areas needing immediate policy intervention. Areas identified include the need for local venture capital for solar enterprises and the need for local (centralized) information exchanges. This can be seen in the STC and Kent. prongrams.

- The TA process can provide a focused arena for the discussion and clarification of community values and goals. A wide range of economic and political interests can usefully plan for the future in the context of underlying goals. All TA communities have shown this characteristic. 
- The TA process serves to mobilize a wide range of local expertise on energy planning and alternative energy applications. Local interest and experience is much wider and much more sophisticated than originally hypotbesized. This is especially true in the STC and Richmond cases.

- The TA process serves to sensitize and educate local constituencies to national as well as local energy problems. In each community the "business as usual" scenario is seen as the most disruptive, or the most threatening.

- TA communities are anxious to implemerit local energy plans which rely heavily upon indigenous, renewable resources.

\subsection{Conclusion}

The second phase of the TAP is expected to be completed by October, 1980. This phase currently contains three major components.

(1) Completion of the community TA's

(2) Integration and assessment of program components

(3) Monitoring and evaluation of community TA's.

It is expected that the TAP will continue in future years, although the overall direction has not yet been finalized. It has been, and remains, a firm conviction on the part of ORNL staff that the community TA assessment-planning process can make a significant contribution to local and national energy development as a policy formulation tool, a policy implementation method, and a vehicle for community evolution and growth. 
FOOTNOTES

1. U. S. Department of Energy, Domestic Policy Review of Solar Energy, Final Report: Impact Panel, TID-28835, October, 1978, p. 3.

2. The Community Energy Act is co-sponsored by Senators Tsongas (D-MA) and Williams (D-NJ). This legislation combines the approaches in the Tsongas bill (S.1829) and the Williams bill (S. 2095) and incorporates the Administration!s Energy Management Partnership Act, as introduced by Senator Percy (R-IL). The Community Energy Act contains four major provisions: Community Energy Block Grants, Energy Project Grants, Technical Assistance and State Energy Conservation Program.

3. Rashid Ahamd and Alexander Christakis, "A Policy-Sensitive Model of Technology Assessment," IEEE Transactions on Systems, Man and Cybernetics, Vol. SMC-9, No. 9, September, 1979.

4. Franklin County Energy Study: A Kenewable Energy Scenario for the Future, Future Studies Program, University of Massachusetts, Amherst, Massachusetts, April 1, 1979; T. O. Carroll and R. Nathans, Solar in Surburbia: A Cace Study on Long Island, Institute for Energy Research, State University of New York at Stony Brook, November, 1979 (draft);

J. Sullivan, R. Cornman and D. Morris. Baltimore: Solar and Conservation Potential by the Year 2000, Institute for Local SelfReliance, Washington; D.C., October, 1979 (draft); W. F. Hornick and G. A. Enk, Value Issues in Technology Assessment, Institute on Man and Science, Rensselaerville, N.Y., 1979. 
FOOTNOTES

5. B. H. Bronfman, M. Scnweitzer, S. A. Carnes, et al., Decentralized Solar Energy Technology Assessment Program: Research Plan, ORNL/TM 6913, Oak Ridge National Laboratory, Oak Ridge, Tennessee, May 1979, pp. 15-17; 41-43. 
THIS PAGE

\section{WAS INTENTIONALLY LEFT BLANK}




\subsection{THE SOUTHERN TIER CENTRAL (New York) T.A,}

In September, 1978, a decentralized solar technology assessment (TA) was begun in the Southern Tier Central (STC) region of New York State; the project was largely completed in FY 1979. Under the guidance of the Southern Tier Central Regional Planning and Development Board, residents of Chemung, Steuben, and Schuyler Counties examined the potential role of renewable energy resources in their regions' future and documented the results. In the following pages, the purpose, group composition, organization and findings of this project will be briefly summarized.

\subsection{Purpose of the STC Solar Technology Assessment}

In the last few years, rising prices and shrinking supplies of energy in the Southern Tier Central region have impressed upon area residents their almost total dependence on imported energy. To many people in this area, "imported energy" refers to any fuel whose availability and cost is determined by policy decisions made outside the region. Accordingly, there is a very real interest in decreasing local dependence on foreign oil as well as on fossil fuels and electricity that are imported or controlled from other parts of the state or nation. By addressing opportunities for the use of decentralized, renewable energy resources within the STC region, the solar TA project represents an important step toward energy selfsufficiency and, as such, speaks directly to a major concern of area residents.

Specifically, this project was designed to involve citizens from a variety of occupations and geographic locations within the region 
in examining how a wide range of renewable energy resources can be used to meet local needs, the social and environmental impacts that could result from that use, and the implementation devices available to achieve desired levels of renewable energy utilization. It was also intended that the experience gained through this project be used by other communities in their attempts to study their own enerqy potentials.

\subsection{Project Participants}

The citizens who participated in the TA project were recruited from a variety of backgrounds in a number of different ways. Volunteers were solicited through radio and newspaper advertisements and also through media coverage of the proposed project designed to elicit local interest. In addition, invitations were extended to specific individuals suggested by various local government agencies. A total of 60 people originally volunteered to take part in this project, and roughly 40 actually turned out for the initial planning session which was held on January 27, 1979. These individuals were then divided into four groups, based on their field of interest. Group I, who dubbed themselves the "humanists," consisted of individuals working in the areas of education, health, religion, the law, or human services. Group II included people engaged in agriculture, natural resourees, or other environmental pursuits. Group III called itself the "military-industrial complex" and was composed of individuals employed by industry, commerce, the utilities, finance, or labor. Lastly, Group IV drew its membership from building, transportation, and community planning. All four groups were aided by a "working team" of STC Planning and Development Board Staff which provided organizational and technical assistance. 


\subsection{Project Organization}

The Solar Technology Assessment Project, which was originally intended to span 15 months, consisted of five major phases running more-or-less consecutively. The five phases were: data collection, education, technology assessment, public policy formulation/public information, and documentation. Each phase will be described in greater detail below.

\section{Data Collection}

The execution of this task began in September, 1978, and signalled the beginning of the TA project. Undertaken by the STC Planning and Development Board Staff, the data collection phase was designed to provide information for the citizens groups and "working team" to use in the upcoming technology assessment phase and also to educate the public at large. The main products resulting from these efforts were a renewable energy resource inventory for the STC region, a handbook on the operation of selected solar and renewable energy technologies, and a citizens' technology assessment workbook to help guide the TA process in the months ahead. ${ }^{1}$ The text for all three volumes was completed in early December and distribution of the final. copies began around the end of January.

Energy consumption data gathered by the STC staff showed that personal energy consumption in New York state had increased by 32.5 percent per capita between 1960 and 1977. The total energy consumption in the three-county area was approximately 15 percent higher than the state level, due to harsher than average winters and greater than average automobile use. In 1976 the citizens of the STC region spent slightly 
more than 10 percent of their disposable income on energy; between 80 and 90 percent of this amount left the region. In Chemung County, the most urban in the region, natural gas is used heavily for residential heating as well as for industrial processes; because of this, the county has been directly impacted by threatened and actual gas curtailments of recent winters. Schuyler County, with the greatest per capita energy use in the region, is highly dependent on gasoline, both for its tourist trade and for the large number of workers commuting to jobs outside the county. Also, a large proportion of Schuyler residences are heated with scarce and expensive fuel oil. Steuben county residents also consume substantial amounts of fuel oil and gasoline but not to the extent of their Schuyler County neighbors. In addition, the region's largest employer, Corning Glass Works, has traditionally relied heavily on natural gas for its manufacturing processes al though it has recently begun to convert to electricity and to vigorously pursue conservation.

\section{Education}

The education phase was designed to inform STC residents about locally available renewable energy resources and about the TA project itself. Small grants $(\$ 500.00)$ were awarded in early January, 1979 , to each of five different public schools in the region for small-scale renewable energy projects (e.g.. the placement of an electricitygenerating wind turbine at one school; the mounting of solar window heaters in the homes of individual students from another school). In addition, information was disseminated to the public through a number of media events such as press conferences, staff appearances on radio 
and TV programs, and presentations on conservation, renewable energy, and technology assessment to various community groups. Finally, after the technology assessment phase was well under way, the task groups and "working team" communicated their progress to other interested parties in the region and received feedback through an informal "community contact network," composed of selected individuals in the three-county region who communicated with the project staff on a regular basis.

\section{Technology Assessment}

The technology assessment phase began in late January, 1979, with the convening of the plenary session for all interested community members, and lasted roughly five months. Initially, the citizen volunteers were divided into four "interest groups," each of which formulated a set of five primary values to guide their subsequent work. Next, each group developed an "unconstrained" renewable energy resources utilization scenario for the entire three-county region based on the premise that the use of imported energy (energy brought in from outside the region) would have to be reduced by $50 \%$ in the next six years. The scenarios detailed the local renewable energy resources that would replace the conventional fuels currently in use, and the social/political/economic/ environmental impacts expected to arise from using these new energy resources were assessed. In light of the projected impacts, these "first-round" energy-use scenarios were then revised so as to mitigate previously identifed adverse effects, yielding final scenarios for each of the four interest groups. These were completed in early May, at which time the interest groups were disbanded and three new groups were formed, 
one for each of the Southern Tier Central Counties. Each group, which included former members of 2.11 the earlier interest groups, then sought input from representatives of their respective local governments in order to come up with new energy-use scenarios and implementation strategies tailored to their particular county. Although not all the groups were met with equal enthusiasm by their government representatives, each completed their final scenario-writing/technology assessment task by carly July. The products of these efforts will be deseribed later in the Documentation and Findings sections.

\section{Public Policy Recommendations/Public Information}

This phase was designed to link the findings of the technology assessment task to local public policy and to solicit public comment on the team's findings. Policies to implement desired renewable energyuse scenarios were formulated by the interest groups initially and later by the county groups with input from local elected officials. Examples of the implementation options that were developed are given in Section 2.4. The original work plan called for a regional "town meeting" on solar energy policy, at which the task teams were to present their findings and get feedback from the general public. Instead, communication with the public at large was accomplished through the community contact network and a press conference hejd in mid-September. In addition, a Volunteer Conference was held at Elmira College in late October at which much give-and-take with area residents occurred.

\section{Documentation}

Documentation was the final stage of the project and was designed to give a final recounting of the activities of all participants during 
the course of the program and to comment on the mechanics of the process. A preliminary report ${ }^{2}$ was issued in May, 1979, on the findings of the four interest groups and a final report ${ }^{3}$ was printed in August after the work of the three county groups was completed. The emphasis was on policies designed to implement desired energy futures rather than on the process by which these were developed. In fact, these documents were both referred to as "plans" for energy conservation and development, reflecting the feeling of team members and the STC Regional Planning and Development Board that the project should, as much as possible, serve the community by pointing the way toward greater local use of renewable energy resources. In addition, a separate history of this project has been compiled by a student intern working for the STC Regional Planning \& Development Board.

The STC Solar Technology Assessment Project, as originally designed, was largely completed by the end of September, 1979, after 13 months of work. A number of ongoing projects remain, however, as a legacy of this effort. At the regional level, the Elmira College Volunteer Center Conference held in late October was designed to continue local involvement in this area, while a Revolving Loan Fund and Energy Advisory Service to Industry are expected to evolve in the months and years ahead. It is expected that county governments will also become increasingly involved in stimulating the use of renewable energy resources as they respond to the policies and implementation strategies suggested for them by the Task Teams' Plans. 


\subsection{Findings}

As mentioned earlier, the final report documenting the findings of the TA task teams was an Energy Conservation and Development Plan ${ }^{3}$ for the Southern Tier Central Region, released in August, 1979. The information presented in this document includes a brief discussion of the need for the TA project and the process involved in executing it, a description of the renewable energy plans developed for Chemung, Steuben, and Schuyler Counties, and detailed presentations on the use of conservation, solar energy, wood, alcohol, methane and wind plus the potential impacts associated with the utilization of each of these technologies. Finally, existing New York state legislation affecting the use of renewable energy resources was listed and the potential impact of local laws on the development of renewables in the STC region was analyzed. The following paragraphs will summarize the major elements of the County energy plans presented in the final report and will offer examples of the kinds of impacts identified as being associated with the use of the various renewable energy resouces examined.

There were certain broad similarities among the plans developed by all three county groups. All felt that the people of the STC region will suffer much more in the future if steps are not taken now toward local energy self-sufficiency and that decisive actions in the short run will produce greater payoffs in the longer term. It was generally believed that the use of "imported" energy resources in the STC region could be cut by $50 \%$ or more within the next 10 years with an all out effort for local energy conservation and renewable energy development. 
It was estimated that by 1985 roughly $35 \%$ of current nontransportation energy consumption could be cut through conservation techniques, $9 \%$ through wood utilization, $8 \%$ through direct solar applications, and less than $1 \%$ through the use of wind power. In 1990, the contribution of conservation, wood, and wind are expected to be roughly the same, but the solar contribution could increase to over 15\%. Of the energy currently consumed in the transportation sector, it is projected that roughly $37 \%$ could be saved by 1985 through conservation and another $18 \%$ through the substitution of ethanol for gasoline. The cost in dollars of this shift away from conventional fuels was not analyzed, but certain basic economic assumptions were made by the STC staff and team members. It was assumed that the price of conventional fuels will continue to rise, that obtaining these scarce fuels will become increasingly difficult and uncertain in the years ahead, that the costs of the renewable energy resources emphasized here will decline in the near-term future relative to the fuels they replace, and that energy independence and security have a value just as real as the dollar costs normally used to evaluate competing technologies.

Actions to conserve conventional energy supplies that were agreed to by a majority of each group include educating the public to a variety of energy-saving habits, insulating and weatherizing all buildings, controlling temperature and lighting levels in all buildings, controlling lighting on highways and in urban areas, increasing transportation efficiencies through measures such as encouraging mass transit, promoting the practice of recycling, and removing existing institutional and financial disincentives to conservation, such as the local practice of 
making government procurements based solely on "front-end" rather than life-cycle costs. It was generally agreed that actions such as these could have a tremendous impact on reducing the energy requirements of the region, as quantified above.

Recommended approaches to encouraging renewable energy production include developing local wood resources through practices such as utilizing wastes and non-saw timber for space heating and boiler fuel, producing alcohol from local crops, producing methane gas from organic waste, greatly increasing the use of passive solar. space heating and active hot water heating, and developing wind turbines at appropriate sites. The fact that local citizens were integrally involved in the development of these ideas increases the likelihood that they will speak to broadly felt local needs and, in turn, be implemented.

While there was not always a consensus on who should implement the above measures (government agencies vs the private sector, individuals vs larger community groups), there was general agreement on what the role of the STC Regional Planning and Development Board should be in these matters. Basically it was felt that the Board should help provide capital for renewable energy and demonstration projects, provide information and technical assistance for conservation and renewable energy development, and foster a citizen-based planning function for local energy conservation and development projects.

While it is not possible to provide an exhaustive listing here, examples will be given below of the kinds of potential impacts that were identified during the technology assessment phase as accompanying the use of various renewable energy resources. It must be remembered 
that by identifying prospective impacts in this fashion and then adjusting the initial scenarios, it was hoped that the final conservation and development plans would minimize the negative impacts and maximize the positive ones associated with the use of the available technologies.

Positive impacts identified as accompanying the use of conservation techniques include the fact that substantial savings can be realized in heating and cooling costs, resale value is added to the structure so equipped, and local investments can increase because less money will have to leave the region to pay for imported energy. Negative factors include, among other things, the danger of lethal fumes from certain types of insulation in the event of fire, the necessity of substantial front-end investment for conservation services and materials, the need for additional transportation and storage facilities to handle recycling requirements, and the possibility that a labor-intensive conservation industry may result in a shortage of workers in other sectors.

Among the positive impacts postulated from the use of solar energy are the likelihood that individuals would gain increased freedom from utility dependence, new jobs would result from the labor required to manufacture, install, and maintain solar equipment, and the need for significant amounts of conventional fuels would be eliminated. On the negative side, front-end costs can be substantial for solar systems, vandalism could present a problem, conmunity aesthetic values might be compromised, and conflicts might result from the need of solar users to keep neighboring property owners from casting shadows on their solar collectors. 
There are many benefits associated with an increased use of wood as an energy source. Most notably, new jobs could be created in the local economy, the flow of money outside the region could be checked, and residents could enjoy more security from blackouts and fuel shortages. Adverse impacts include the possibility of fire, accidents, wood theft, increased air pollution, and the fact that heating with wood requires substantial time and effort.

As with wood, the use of locally produced alcohol for fuel could also improve the local economy by lessening expenditures outside the region and increasing local employment. It is projected that the local tax base could also be strengthened. On the negative side, the use of prime land to grow fuel crops could result in dwindling supplies and higher prices for human food and animal feed, and increased 1 and competition and rising land taxes could hurt local farmers.

Finally, the use of large wind turbines combined with the pumped storage of water could help area residents by reducing their dependence on imported fuels and by increasing the availability of water for drinking, agriculture, and recreational use. Negative impacts include possible aesthetic problems, the danger of accidents from blade failure or breakage, and the chance that TV and radio reception may be adversely affected. 


\section{FOOTNOTES}

1. The three reports referenced in the text have been condensed into a single volume entitled Renewable Energy Resource and Technology Assessment, ORNL/SUB-7549-1, available from the National Technical Information Service, U.S. Department of Commerce, Springfield, Virginia 22161.

2. Plan for Local Energy Conservation and Development, Southern

Tier Central Region, New York. Preliminary Version. May, 1979. Available from Southern Tier Central Regional Planning and

Development Board, 53 1/2 Bridge Street, Corning, N.Y. 14830

3. Southern Tier Central Regional Planning and Development Board, Energy Conservation and Development Plan, Southern Tier Central Region, New York. Available from Southern Tier Central Regional Planning and Development Board, 53 1/2 Bridge Street, Corning, N.Y. 14830. 


\section{THIS PAGE}

\section{WAS INTENTIONALLY LEFT BLANK}




\subsection{RICHMOND, KENTUCKY. T.A.}

Selection of a southern community to participate in the TAP began in March, 1979. Over one hundred notices of the "Request for Proposal" were sent to local governments, universities, and planning associations in the $O R N L$ region. Fifteen proposals were submitted to ORNL, and after a careful screening and evaluation, two proposals were selected for site visits by ORNL staff to facilitate the final determination of the southern community. Richmond (Kentucky) was selected in Apri1, 1979, and the contract between ORNL and Eastern Kentucky University (EKU), representing Richmond, came into effect June $1,1979$.

The EKU/Richmond proposal was fully responsive to the ORNL Request for Proposals (RFP). It had, and continues to have, competent local expertise and cooperation among the task team (composed largely of University faculty), the Community Assessment Group (representing major sectors in the local economic and social system, including university students), and the City of Richmond. The proposal was preceded by a University-sponsored survey of Richmond citizens (initial results available). The survey addressed socioeconomic and demographic characteristics, knowiedge about energy supply and conservation with an emphasis on solar power, and the role of citizen participation in local communtty affairs. EKU plans to resurvey the citizenry after the technology assessment program and their contract with ORNL are both completed. 
Most of the proposed tasks are being completed according to the original proposed schedule. A short report on progress to date (December 31,1979 ) on each of the tasks set out in the proposal includes an identification of individual and generic project implementation problems that may have developed or be developing and suggested solutions.

\section{Task I - Phase I}

Organization and Profile Construction - There was some initial lag in getting the project organized -- some of the task team members took already planned vacations during the summer months. The Project Work Plan was submitted in mid-July, and was reviewed and approved by ORNL. in mid-August.

\section{Task I - Phase 2}

Recruit and Convene Community Assessment Group - A major early function of the tàsk team was to recruit a Community Assessment Group (CAG) which is responsible for formulating alternative energy scenarios and organizing and implementing the Community assessment. The task team was not completely successful in developing the comprehensive grassroots support for the project that it had envisioned. A few of the initial supporters of the program, including the ex-city manager and a local banker, have not continued their support at expected levels. Such variation in support should probably be considered as "normal" for such efforts. Public participation is bound to wax and wane since individuals' memberships in and commitments to voluntary associations change over time.

The task team is aware of this problem and is attempting to correct it. Numerous public meetings have been held. While each meeting 
was announced as being open to the public, representatives of various community groups were specifically invited to attend.

The CAG has organized itself into a number of working committees, including a solar applications group, a scenario development group, a. TV production group, a group concerned with institutional issues, a student symposium steering committee, a community involvement group, a community education and awareness group, and a group concerned with the preparation of non-TV audiovisual materials. From this organization one sees a heavy emphasis on community education and public participation and interest in demonstrating renewable energy applications.

The coordination of participation in the early stage of the assessment program has been somewhat problematic. While some of the identified representatives have not participated, the program has attracted the attention of some members of the public who wish to work actively on demonstrating solar technologies and applications (rather than on the assessment itself). This "spin-off" of the TAP was apparently not anticipated by the Task Team, and coordination of the TAP with local solar advocacy has proved problematic. The task team planned on procuring participants and leaders from established social and economic groups in the community. While many of the participants to date do represent such groups, other individuals (including EKU students) are playing an important role in the Community Assessment Group's work. Interestingly, these individuals are supplying creative and imaginative elements to the TAP which might otherwise have been missing. 
The role of the university, and particularly its students, in this or any of the other TAP university communities is being carefully monitored. There is a considerable literature on the "town-gown" split, its problems and its potential. Students, particularly in regional universities (defined as those which attract a majority of their students from nearby areas) where many graduates remain in the area, can play a key role in mediating between university professionals and their resources and a lay community. Students' resources may include: (1) a strong identity with the region and concern with its future; (2) time (generally an elastic resource); and, (3) an on-going 3-6 year liaison with the university.

Programs such as the TAP could, depending on participation levels and idiosyncratic variables, increase the integration and cooperation between the community and the university.*

Task I - Phase 3

Community Profile - EKU has obtained most of the data required in the community profile. Some of these data have been organized and analyzed for the program's participants' manual, a draft of which has been submitted and reviewed by ORNL. Other data, not used in the manual but which will continuc to bc uscful in the implementation of the program and in the preparation of the final report, have been obtained on census and demographic characteristics of the community and its history.

*If regional university communities can take a lead role in diffusing energy technologies and their potential applications, they might serve as regional innovators. For larger urban communities with two or more universities, coordination and management of the relationships becomes more problematic. 
Community planning decisions, energy profiles and solar energy data (some of which appears in the manual) will also be useful to the implementation of the program. Preliminary analysis of Richmond's survey indicates that almost two-thirds of its residences are heated by natural gas and one-third by electricity and that more than half the respondents have two or more cars. Almost 70 percent of the respondents, in a community which is fairly densely populated and seems amenable to mass transportation, use their private automobiles to commute to and from work. More than half the respondents have never improved their home insulation, and only 20 percent have improved home insulation since 1975.

Task I - Phase 4

Analysis of Alternative Participation Programs - EKU is still developing its community participation program. Participation within the CAG structure appears to be developing through a self-selection process for various conmittee assignments (e.g., scenario development, legal and institutional issues, the role of local commercial and small businesses, the role of solar demonstrations in the program, etc.). This approach is likely to continue throughout the duration of the project.

Participation methods for the rest of the assessment process have not been determined. Energy fairs, neighborhood and other organizational meetings have been used during the education task (discussed below). Task I - Phase 5 Solar Energy Reconnaissance - This task, which is scheduled to run throughout the community assessment, is continuing. It involves the 
collection and synthesis of current and projected energy use data for Richmond, the preparation of renewable energy educational materials, identification of institutional barriers to the use of renewable energy technologies in Richmond, and monitoring of conservation and renewable energy efforts being taken elsewhere (e.g., other communities, states, and federal government).

Task $\bar{I}$ - Phase 6

Participants Manual - The first draft of Solar Options: Local Assessment by Richmond (SOLAR), a manual prepared by the project staff for participants on the Community Assessment Group, was completed in September, 1979, and reviewed by ORNL and other DSETAP participants in October, 1979. The Community Assessment Group will use SOLAR as a common information base to guide the group as it assesses the feasibility of various locally-available energy supply options and the impacts of those options. The manual discusses methods by which citizens of Richmond can replace their current reliance on fossil fuel energy resources with renewable resources. The bulk of the report deals with conservation and active and passive solar homes and their economies for the current electric, natural gas, and fuel oil home. The report also discusses various biomass and wind technologies.

The final version of SOLAR will expand its considerations of conservation as an energy supply option and will address, in a preliminary and introductory way, how the community would be affected by the deployment of any of the discussed alternatives. Information presented in SOLAR will help the group and the community focus their attention on a number of discrete energy options. 


\section{Task II - Scenario Development}

The scenario development task began in the early fall of 1979 and continues through Task III (Community Involvement and Education). The Richmond TA is considering three scenarios: a "business as usual" scenario, which is an extension of the present energy supply system; a plausible solar scenario based on existing levels of knowledge; and an expanded solar scenario based on a consideration of indigenous renewable energy resources, alternative energy demand projections reflecting differing assumptions, community values and goals, impacts of al ternative renewable energy supply systems, and potential sources of local conflict and means of conflict resolution.

\section{Task III - Educational Programs}

The solar applications, TV production, student symposium, community involvement, community education and awareness, and audiovisual groups of the CAG are all working on educating the citizenry of Richmond about the TA project and conservation and renewable energy technologies and their application in Richmond. The diversity of groups dedicated to this task apparently reflects differences in preferred approaches by members of the CAG.

As mentioned earlier, some members are convinced that the public should be exposed to demonstrations of renewable technologies (e.g., solar homes, greenhouses, windmills, etc.) and that "hands-on" experience is vital to the deployment of renewable technologies by the public at large. To this end the CAG has offered and is continuing to offer numerous opportunities for citizen familiarization with renewable 
energy technologies. These have included visits to solar homes and a mobile solar energy fair. The mobile solar energy fair, which demonstrated solar space heating, solar hot water heating, a solar greenhouse, energy-conserving window coverings, and solar cooking and featured a puppet show and slide tape presentations on solar energy information, was taken to eight neighborhoods in. Richmond on successive weekends in November and December, 1979, and attracted over 500 different participants. Many of these participants have since become active in the Richmond TA, and plan to be active in special "hands-on" workshops in February and March.

The CAG also established a lending library on alternative energy technologies at the Richmond Chamber of Commerce and sponsored open discussion meetings with outside "experts." These consultants included David Pomerantz of the Franklin County TA, Bert Swanson of the University of Florida (an expert on community and neighborhood action and development), Ann Cline of Richmond, Indiana, (Richmond, Kentucky's, sister city and one of the seventeen communities working on DOE's Comprehensive Community Energy Management Program - CCEMP), and Norton Long, a noted community sociologist. At the end of December the CAG was also working on a TV production to be aired on the local educational channel and newspaper supplements to be distributed in the near future. Task IV - Community Assessment

Under this task, scheduled to take place in February, March, and April, the community will evaluate the technical, environmental, economic, social, and political impacts associated with each energy 
scenario. These evaluations are planned to evolve from meetings in various neighborhoods of the community.

Task V - Final Report

The final report of the Richmond TA is scheduled to be completed by May 31, 1980. Project management (Janet Patton and J. Allen Singleton of Eastern Kentucky University) is responsible for completing this task. Polly Gage, the Richmond TA project historian will also contribute in the completion of this task. 


\section{THIS PAGE}

\section{WAS INTENTIONALLY \\ LEFT BLANK}


4. 0 KENT, OHIO, T.A.

The Kent, Ohio, TA project was selected as the Midwest region representative from 17 proposals received by Argonne National Laboratory resulting from the distribution of approximately 100 RFPs. The criteria for selection of the community were agreed to by ANL and ORNL. Although the Southeast and Midwest communities were selected at the same time (June, 1979), the Kent project requested and received permission to extend the lengti of their project to 15 months, extending the early planning and TA team selection over the summer.

As of October, 1979, the task team members had been selected, a revised, detailed project plan completed, and baseline data collected.

The TA task team, which developed the revised program plan, is composed of 24 members. Members were selected on the basis of expertise in areas important to the project, or as representatives of selected community interests.

The revised, detailed project plan, completed on September 30, 1979, set forth milestones, deliverables, and timetables for each of the five major subtasks of the Kent program.

1. Selection of task team and development of detailed project plan.

2. Development of community solar future scenarios.

3. Communication of scenarios to the community.

4. Scenario assessment.

5. Policy analysis, assessment, manual, and final report. The development of the community solar future entailed the completion of a baseline statement of energy use in kent. 
The analysis of current use patterns is designed to provide an energy profile for the community. This profile will be used to make projections about future use. The attitudinal information will be used to establish the parameters for the projections. It is hoped that the combined use of baseline statistics and local preferences will be reflected in a more realistic future scenario for Kent.

The community energy profile for Kent, in 1979, showed (excluding transportation fuels) that 16.7 percent of energy used is electricity. 78.1 percent natural gas, 1.5 percent fuel $011,2.6$ percent coal, 1.9 percent L.P. gas and less than 0.1 percent wood. The high dependence upon natural gas has heightened Kent's awareness of their vulnerability to energy supply disruption. Results of the questionnaire and analysis of current energy use indicated two major areas requiring immediate attention: (1) Mandating of conservation, especially of nonrenewable resources and; (2) replacing as much traditinnally produced energy as possible with renewable energy resources.

For the period ending November 30, 1979, three solar scenarios were completed reflecting three time horizons:

1. Short-rangc (to 1085)

2. Medium-range (to 1990)

3. Long-range (to 2000).

The project task team took the primary responsibility of this task, with inputs from the project staff and the Kent Citizens Advisory Board. The three scenarios are being designed to reflect "optimum representative" cases, combining available technologies and community preference. 
The initial short-range scenario (1985) calls for an emphasis upon conservation and education. Mandatory energy audits and more stringent building code requirements are part of this scenario. Additionally, the scenario projects an increasing number of renewable energy demonstration projects, as well as passive solar demonstrations. Finally, minimum criteria for energy efficiency for appliances are required.

The medium-range scenario (1990) calls for an overall reduction of electricity utilization and nonrenewable energy utilization by 25 percent over 1980 levels. Local mandates for 30 percent home heating with solar energy are instituted. Commercial establishments must have 50 percent of their energy requirements met by renewable and solar energy. New commercial establishments specializing in renewable resources are growing by 300 percent over 1980 figures. Industry is encouraged to use solar industrial process heat for low-temperature processes. Mandatory energy recycling can be expected to provide virtually all space heating needs, and 15 percent of electrical needs. Applications featuring photovoltaics are introduced. Finally, the City of Kent has developed a municipally-owned biomass conversion facility, and has weatherized all public buildings.

The long-range scenario calls for a reduction of 50 percent in nonrenewable energy sources over 1980 levels. This is made possible through the extensive utilization of conservation and renewable energy technologies. The community will change in many ways. Local energy coops for shared systems are developed. New housing includes underground homes and extensive use of photovoltaics and solar ponds. 
The commercial sector is well on its way toward energy selfsufficiency. Shared systems characterize the central business district. Some decentralization of light manufacturing has encouraged neighborhood cottage industries. Energy savings in the industrial sector will depend primarily upon the development of hardware systems in the experimental style in the 1980's. Industrial parks surrounding shared systems such as biomass conversion, solar collector systems, or wind turbine "fields" are developed. Excess energy is sold to the residential and commercial sectors. Local government is seen to be much smaller. Public institutions operate on schedules determined by energy efficiency. The City of Kent is expected to operate totally on energy sources supplied from nonutility sources

Upon completion of the construction of the first threee solar scenarios, the proiect has moved to provide a wide range of citizen inbut to the scenario process through a community meeting. The meeting will be open to the public but will also have invitiations issued to selected individuals. The target size for the public meeting is 100-150 individuals.

Utilizing Nomimai Group Technique (NGT), various meeting subgroups will be asked to consider the potential costs and benefits to the community from the increased use of solar energy. Some groups will consider short-range, medium-range, or long-range benefits. Products of these sessions $w_{111}$ be used by the lask team to refine the preliminary scenarios and produce final scenarios.

The final stage of the scenario development task will be to develop a transition scenario for each end-state scenario. The purpose of the 
transition scenarios is to identify the actors and resources necessary to achieve the desired results of the three end-state scenarios. The task team and selected consultants and experts will develop three transition scenarios which will:

1. identify critical decision-points

2. identify decision-response alternatives

3. identify achievement milestones for scenario objectives.

The scenario development task currently underway is expected to be completed by Januapy, 1980, whereupon a three-month communication effort will begin, designed to communicate the finalized end-state and transition scenarios to the community at large.

Project manager for the Kent program is John 0strowski, with additional support staff provided by Kent City Manager, Roy Stype. 
THIS PAGE

WAS INTENTIONALLY

LEFT BLANK 


\subsection{FRANKLIN COUNTY, MASSACHUSETTS T.A.}

The Frankl in County Community Technology Assessment was begun in October, 1979. The solar scenario contained in the Franklin County Energy Study forms the basis for the Technology Assessment. The scenario presented in the Franklin County Energy Study assumes that: (1) in the year 2000, Franklin County can obtain a significant amount of its energy requirements (virtually all of its electricity and heating demands) from renewable resources, (2) the money saved by residents for energy obtained from renewable resources will result in a higher county standard of living, (3) focus on energy problems will result in a greater sensitivity to other community issues, and (4) a greater comprehension of alternative energy futures will result in greater community political actions to support conservation and renewable resource options.

The Franklin County Energy Study showed that in 1975, the industrial sector had 13 percent of the total energy use, the residential sector had 28 percent, the commercial sector 31 percent and the transportation sector 28 percent. In terms of cusl, each sector showed a moderate increase in energy cost between 1950 and 1970 and a sharp escalation in energy costs between 1970 and 1975. In constant dollars, the average energy cost, across all sectors rose from $\$ 1.25$ per $10^{6} \mathrm{~kJ}\left(\$ 1.32\right.$ per $10^{6}$ BTU) to $\$ 1.70$ per $10^{6} \mathrm{~kJ} \$ 1.79$ per $10^{6}$ BTU) by 1970 and jumped to $\$ 3.74$ per $10^{6} \mathrm{~kJ}\left(\$ 3.95\right.$ per $10^{6}$ BTU) by 1975 . An attitude survey of local residents, conducted in 1978, showed a strong commitment to conservation (93 percent of the sample said they had reduced energy consumption since 1973) and a willingness to pay 
more for appliances initially if it meant energy savings later on. Approximately 25 percent of the sample used wood as a secondary heat source, with 14 percent using wood as a primary source. In terms of alternative energy preferences, the largest proportion of the population (59 percent) favored developing hydroelectric power, and, lesser proportions favored wood (55 percent), solar (39 percent), waste recycling (31 percent), and wind (21 percent).

The scenarin developed utilizes solar encrqy primarily for promiss and space heat and hot water. Hydroelectric and wind systems are projected to be used to generate electricity. Biomass applications run the gamut from transportation fuels and natural gas substitutes to space heating and process heat.

The TA task team has been formed from the existing Franklin County Energy Conservation Task Force, composed of over 30 local citizens, professionals, business persons, government and utility representatives. This format was chosen to ensure that wide exposure to the TAP within the county would be forthcoming from the beginning of the program.

The Franklin County TA is compnsen of four major tasks:

I. Activation of the Technology Assessment Team (two months)

This task includes familiarization with the TA program and plans, developing a methodological approach for citizen involvement, developing an assessment workbook for use in the county-wide assessment, and development of a presentation plan for the scenario developed in the Franklin County Energy Study. 
II. Evaluation of the Scenario by the TA Team (one month)

Before the county-wide TA is undertaken, the TA team will undertake its own assessment of the scenario in terms of the shortand long-term social, economic, environmental, and life-style consequences. Additionally, the TA team will suggest alternative programs for individuals, the county, and towns to pursue to foster the development of renewable energy resources. The community involvement plan, developed in Stage $I$, will be finalized.

III. County Assessment of Solar Scenario (two months)

The county assessment will be undertaken at several subcountv meetings. The meetings will involve the description and evaluations of the solar scenario developed in Task II and presentation of ideas for programs at the county, town, and individual level, also developed in Task II. Members of the TA team in whose region the meeting took place will be involved in evaluating the results of the regional meetings.

IV. Policy Analysis/Final Report

The TA team will evaluate the regional meetings, citizen involvement, programs the county, towns and individuals can pursue, and where outside assistance from state and federal agencies is necessary. A final report will be written and submitted to the County Commissioners, the Energy Conservation Task Force, ORNL, and DOE. The report will contain a review of the Franklin Countu. Energy Study and solar scenario, an overview and description of the methodology of the TA prograrn, results of the study, and recommendations from the TA team. Finally, the TA exercise will be placed in the context of ongoing energy activities in the county area. 
The Franklin County TA study began on October 14 and is expected to be completed by May 30, 1980. Principal Investigators are David Pomerantz and Mark Cherniak of the Northeast Appropriate Technology Network, Inc., Greenfield, Massachusetts. 


\section{FOOTNOTES}

1. Franklin County Energy Study: A Renewable Energy Scenario for the Future, Futures Studies Program, University of Massachusetts, Amherst, MA, Apri1, 1979. 


\section{THIS PAGE WAS INTENTIONALLY LEFT BLANK}




\subsection{REVIEW OF SOLAR LEGAL AND INSTITUTIONAL ISSUES}

The process of achieving widespread utilization of solar energy systems involves more than just perfecting the physical workings of the appropriate technologies. A broad range of legal and institutional issues must also be faced if solar energy is to contribute significantly to our national energy supply. The following pages summarize the major findings of a recently completed report based on a comprehensive literature review of this subject area. ${ }^{1}$ The five major issues identified in that report will be briefly discussed here, along

- with their potential impacts on the solar commercialization effort. A brief description of the most influential participants in the solar field, from both the public and private sectors, will follow. Finally, implementation options for governments seeking to remove existing impediments and create new incentives for solar use will be discussed.

\subsection{The Major Issues}

Prohibitions on the Use of Solar Equipment

Provisions of various public statutes and private agreements, such as zoning ordinances and restrictive covenants, can act to prohibit the use of solar energy systems by prospective users. While generally unintended, the effects are nonetheless real, as where height restrictions preclude the installation of rooftop solar collectors. ${ }^{2}$ Unless modified, such restrictions can effectively outlaw the use of solar equipment and are a serious barrier to the widespread use of this energy source. 
Regulation of Production and Placement of Solar Equipment

Regulations that cover the production and placement of solar energy systems have the potential to either help or hinder the solar commercialization effort. Strong product warranties, for example, could encourage consumers to purchase solar equipment while the lack of same may inhibit market penetration. ${ }^{3}$ Similarly, it is widely believed that the development of solar codes and standards can further solar usage, both by encouraging acceptance by consumers and lenders 4 and by simplifying the process of receiving the necessary construction permits from local officials. ${ }^{5}$ Other related subissues concern the role of unions, ${ }^{6}$ the licensing of solar installers, ${ }^{7}$ requirements for mandatory installation of solar equipment, ${ }^{8}$ questions of competition in the solar industry, ${ }^{9}$ the riability of solar businesses for system malfunctions and resulting damages, ${ }^{10}$ and government policies concerning patents and 1 icenses. 11

Access to Sunlight

The importance of protecting the solar user's access to sunlight is obvious; without adequate insolation, his solar system will not function properly. The major approaches to assuring solar access are through the use of "sunrights," 12 established land use controls such as zoning and subdivision regulations, ${ }^{13}$ and other legal devices such as easements and deed restrictions. ${ }^{14}$ Without adequate access protection, prospective solar users are likely to be reluctant to invest in costly solar equipment, to the detriment of the solar commercialization effort.

Financial Incentives and Impediments to the Use of Solar Technologies

In addition to the purchase price, a number of other factors affect the economic attractiveness of solar systems. Property, sales, and 
income tax rates can all play a role in determining the total life cycle cost of a solar system to its owner. ${ }^{15}$ Lending policies and interest rates can also be of great economic importance due to the frequently substantial front-end costs of the required equipment. 16 The price of other available energy sources is often cited as an important factor in the consumer decision of whether or not to "go solar"; changes in government regulation of conventional fuel prices could do much to change solar's competitive position in relation to these resources. ${ }^{17}$ Government policies toward the direct procurement of solar equipment for public use can also affect solar costs; it has been suggested that such government purchases could stimulate the solar industry sufficiently to result in economies of scale and lower prices to consumers. 18 Finally, the availability and costs of damage and liability insurance for solar systems can affect the attractiveness of the solar option as perceived by potential users. 19 The policies pursued in all the above areas can either encourage or inhibit further solar use by their impacts on overall sys tem cost.

The Public Utility - Solar User Interface

The final issue identified concerns the interface between solar users and the public utilities. The policies developed by these entities and the Public Utility Commissions that regulate them can have a major impact on the viability of the utilities themselves and on prospective solar buyers deciding whether or not to "go solar." The rates charged for back-up power can be central in determining how much 
money will be saved by switching from conventional fuels which, in turn, is very important in influencing the potential solar user's decision. 20 Utility service policies, 21 arrangements for "buying back" excess solar-generated electricity, ${ }^{22}$ and utility programs to furnish their customers with solar equipment ${ }^{23}$ also affect the attractiveness of the solar option and can all be manipulated to either promote or inhibit further solar use.

While it is tempting to look for a relative order of importance to the issues presented above, any such ordering would be open to question and is likely to contribute little to our working knowledge of this field. For instance, some observers may be inclined to single out financial incentives and impediments to solar use as being of primary importance because these affect the cost of solar systems which, in turn, is considered central to many prospective buyers. However, costs are also directly impacted by the utility-solar user interface as well as by certain elements of the production and placement issue. And even if costs are brought down by diligent attention to one or all of these issues, this would not assure that the necessary solar access will be available to potential users or that existing prohibitions against solar use will be removed. All of the issues presented previously, therefore, are important in their own right and none can be ignored if widespread solar use is to become a reality.

\subsection{The Major Actors}

The major solar legal and institutional issues involve participants from both the private and public sectors. The most important private 
actors include the manufacturers and installers of solar equipment, lending institutions, labor unions, insurance companies, utilities, solar users themselves, and other community property owners. The activities of these groups can be strongly influenced by the programs adopted by local, state, and federal governments. The following section will present a discussion of implementation options available to governments at each level seeking to encourage the solar commercialization effort.

\subsection{Implementation Options for Governments Seeking to Further Solar Commercialization}

A variety of options are available for all levels of government seeking to get involved in the formulation of policies and programs to address the legal and institutional issues identified here. The appropriate response will vary among the different government levels, but each is capable of assuming an active role in this important field. The options discussed below are drawn largely from examples of past potential government actions. 24

\section{Local Governments}

Because of their traditional role in regulating land use, local governments are particularly well-suited to deal with the solar access and prohibitions on solar use issues, where land use controls can be most important. Communities interested in furthering solar commercialization can adopt goals promoting solar use and calling for desired levels of solar access and can also draft a statement of purpose declaring solar energy use to be in the public interest. 
Specific actions open to local governments to remove prohibitions against solar use include modifying zoning ordinances, aesthetic controls, and building codes, and outlawing future restrictive covenants that forbid solar use. To assure that locally desired levels of solar access are protected, counties and municipalities can, among other things, utilize zoning techniques, subdivision regulations, and vegetation controls designed for that purpose, and affirm the right of individual property owners to privately negotiate solar easements.

Local governments can take actions in other issue areas as well. In the regulation of production and placement of solar equipment, the goal of promoting solar usage can lead to the adoption of solar standards and codes, the development of standards for licensing of solar installers, and the passage of ordinances mandating solar use under specified conditions. To overcome existing financial impediments to solar use and create new incentives, counties and municipalities can grant solar users property and sales tax exemptions, incorporate solar technologies into public buildings for demonstration purposes, and use life-cycle costing instead of traditional first-cost comparisons to Judge the cost-effectiveness of proposed capital improvements. Finally, municipally owned power companies in locales seeking to further solar use can develop programs to sell, lease, or finance solar systems in their service areas.

\section{State Government}

As with local governments, states can also manifest their interest in encouraging solar use through the adoption of solar 
development goals and a declaration of the public benefit of solar energy utilization. Specific actions are open to the states in all the issue areas mentioned above, with a greater variety of options than is available to local units of government. Where local involvement is possible, state governments can pass enabling legislation making explicit the right of local governments to adopt the needed legislation; they can develop model codes which their locales can adopt at their own choosing or can offer financial and technical assistance to help local governments develop their own measures; they can mandate that local governments adopt legislation meeting certain state-specified minimum standards; and finally, they can act preemptively and adopt regulatory mechanisms that are automatically applicable at the local level. The states can choose from among the above options based on local government interests and abilities and the perceived urgency of implementing the appropriate regulatory devices.

As mentioned earlier, prohibitions on solar use can be removed through properly designed modifications to zoning ordinances, aesthetic controls, building codes, and restrictive covenants. To protect solar access, zoning techniques, subdivision regulations, and vegetation controls that assure current and prospective solar users desired levels of access to sunlight are all available. The states can also provide for the use of privately negotiated solar easements and require solar access considerations to be included in any necessary environmental impact statements. 
Concerning the regulation of production and placement of solar equipment, options available to the states include the establishment of solar equipment certification programs, the creation of appropriate requirements for the licensing of solar installers, and the passage of legislation mandating solar use under specified conditions.

State governments seeking to further solar commercialization can also address the issue of financial incentives and impediments to solar use. Solar equipment can be exempted from property and sales taxes, while a variety of income tax incentives of solar users can likewise be allowed. The states can also adopt measures to make financing available to prospective solar users and can attempt to stimulate the solar market through the direct purchase of solar equipment for public buildings.

Because of their traditional role in this area, the states are in a strong position to regulate the actions of the privately owned utilities in ways that can further solar use. Rates charged for back-up power, utility service policies, arrangements whereby power companies "buyback" solar-generated electricity from their customers, and the pros and cons associated with utility supply and financing of solar equipment can all be carefully studied and appropriate actions chosen to encourage the solar commercialization effort.

\section{Federal Government}

Solar use can be encouraged by carefully designed federal actions in all the issue areas previously discussed. To remove existing prohibitions on solar use, the federal government could attempt to promulgate 
mandatory or preemptive zoning ordinances, aesthetic controls, and building codes, but a less controversial approach is for states and locales to be influenced to adopt the appropriate measure through conditions placed on the granting of federal funds. Model acts can also be developed and their adoption by lower government levels encouraged. To encourage solar access protection, the same options are available. Appropriate zoning ordiances, subdivision regulations, or vegetation controls can be adopted for local and state governments in a preemptive or mandatory fashion, or the passage of such measures can be encouraged through the astute application of financial aid programs. The approach chosen can be based on the perceived urgency of the need to promote solar use and the effectiveness of state and local efforts in this area.

The potential federal role in regulating the production and placement of solar equipment is considerable. Available options include government underwriting of comprehensive service contracts, the establishment of a Solar Energy Labor Board, and the extension of financial aid to small solar businesses.

In the area of financial incentives and impediments to solar use, the federal government could encourage states and locales to grant tax exemptions to solar users through various financial aid programs. Existing income tax incentives can also be examined and possible modifications evaluated in light of their costs and potential for increasing solar use. The availability of funding for solar installations could be addressed by actions such as establishing a Solar Energy Development Bank to provide low-interest solar loans 
and modifying federal mortgage insurance guidelines to allow larger loans at higher loan to cost ratios for solar structures. In addition, modifications can be made to the various federal programs that contribute to artificaliy cheap prices for conventional fuels, additional direct procurement of solar equipment can be undertaken, and government-sponsored property and liability insurance programs for solar owners can be established.

While the primary responsibility for regulating utility practices traditionally rests with the states, there is room for federal action to address the interface between the power companies and solar users. Possibilities for federal initiatives in this area include the adoption of desired back-up rates for the states through preemptive or mandatory legislation and the exercise of increased control over "buy back" arrangements and service policies. Finaliy, the terms of the National Energy Conservation Policy Act can be modified to allow a stronger utility role, particularly in the area of financing, while still insuring against unfair competition and pricing.

In summary, there are a number of important legal and institutional issues in the solar energy field, each of which can be addressed in different ways by the various levels of government. As these issue areas are given increased attention, it is expected that continuing progress will be made in eliminating old barriers and creating new incentives to solar use. 


\section{FOOTNOTES}

1. M. Schweitzer, Review of Solar Legal and Institutional Issues in the Use of Decentralized Solar Energy Systems. ORNL/TM-7078, Oak Ridge National Laboratory, Oak Ridge, TN, April, 1980.

2. Martin Jaffee and Duncan Erley, Protecting Solar Access for Residential Development: A Guidebook for Planning Officials

(Washington, D.C.: U. S. Department of Housing and Urban Development, 1979), pp. 46-50.

3. J. P. Eberhard et. al., Early Use of Solar Energy In Buildings: A Study of Barrters and Incentives to the Widespread Use of Solar Heating and Cooling Systems (Springfield, VA: National Technical Information Service, 1976), pp. 154-56.

4. "Standards Status," Dimensions/NBS (January 1978) p. 21.

5. A. S. Miller, et. al., Legal Barriers to Solar Heating and Cooling of Buildings (Washington, D.C.: Environmental Law Institute, 1977) pp. $49-50$.

6. Miller, op. cit., note 4 , pp. 154-6.

7. Telephone Interview with Alex Bablot, California State Contractors' Board, June 26, 1979.

8. "Rule Requiring Solar-Heat Units Seen as a Pioneer Effort on Coast," N. Y. Times, December 17, 1978.

9. Richard L. Schmalensee, "Promoting Competition in Tomorrow's Markets for Solar Energy Systems" in The Solar Market: Proceedings of the Symposium on Competition in the Solar Energy Industry (Washington, D.C.: U. S. Government Printing Office, 1978), pp. 123-5. 
10. Miller, op. cit., note 4. pp. 172-74.

11. Schmalensee, op. cit., note 8, pp. 129-31.

12. A Forum on Solar Access: Proceedings of a Forum on Solar Access held by the New York State Legislative Commission on Energy Systems (Washington, D.C.: National Solar Heating and Cooling Information Center, 1977), pp. 22-27.

13. Jaffee and Erley, op. cit., note 1, pp. 46 and 82-88.

14. Gail Boyer Hayes, Solar Access Law: Protecting Access to Sunlight for Solar Energy Systems (Washington, D.C.: Environmental Law Institute, May 1979), pp. 111-113.

15. Proceedings of the Workshop on Solar Energy and the Law, February 10, 1975, Arlington, Virginia (Chicago, Illinois: American Bar Fouridaliun, 1975), $\mu \mu$. 11-12.

16. H. C. Peterson, The Impact of Tax Incentives \& Auxiliary Fuel Prices on the Utilization Rate of Solar Energy Space Conditioning (Springfield, VA: National Technical Information Service, 1976), p. 79 .

17. Arthur D. Little, Inc., Residential Solar Heating and Cooling Constraints and Incentives. A Review of the Literature (Washington, D.C.: U. S. Department of Housting and Urban Development, 1976), pp. $26-27$.

18. Interim Policy Options for Commercialization of Solar Heating and Cooling Systems (Washington, D.C.: U. S. Energy Research and Development Administration, 1977), pp. 8-9. 
19. Proceedings, op. cit., note 14, p. 13.

20. Miller, op. cit., note 4, pp. 94-97.

21. Miller, op. cit., note 4, pp. 92-93.

22. Written communication from Bruce Landrey, Portland General Electric Co., May 18, 1979.

23. Application of Solar Technology to Today's Energy Needs, vol. I.

(Washington, D.C.: U. S. Congress Office of Technology Assessment, June, 1978), pp. 125-127.

24. M. Schweitzer, Review of Solar Legal and Institutional Issues in the Use of Decentralized Solar Energy Systems, ORNL/TM-7808, Oak Ridge National Laboratory, Oak Ridge, TN, April, 1980. See especially Chapters 2-6. 
THIS PAGE

WAS INTENTIONALLY

LEFT BLANK 


\subsection{SOCIAL CONSIDERATIONS RELATIVE TO DECENTRALIZED SOLAR TECHNOLOGIES}

The dual purposes of this task ${ }^{1}$ are to devise appropriate social impact categories and to develop preliminary assessments of social impacts, social considerations, and, eventually, social costs for decentralized solar technologies.

The problems confronting this assessment are considerable. They include the nontransferability of many impact assessment procedures of centralized energy systems, uncertainties or variability in the form of many decentralized solar technologies, proponent rhetoric and the usual dilemmas of social impact assessment. Using the narrow sitespecific impact assessment framework applied to centralized systems (estimation of changes in population, impacts upon community services, tax and fiscal effects, etc) from construction or operation of a particular facility ${ }^{2,3}$ would result in overlooking major features of decentralized technologies which differentiate them from centralized technologies and which are the source of major potential impacts. These key differences include:

- the diffuse, variable, and intermittent nature of solar insolation;

- the multiple settings for decision making concerning adoption and use of the technologies (individual, group, community, industry, cooperative, etc.);

- the multiple decision-makers involved (thousands rather than a few dozen); 
- the necessity (and/or goal of) maximizing end-use efficiency in order to compensate for reduced intensity and flexibility of the energy source;

- the need for backup power and/or energy storage facilities or the decision to accept periodic nonavalability of energy

Solar technology uncertainties stem from the myriad alternatives to be considered (exisling, probable, and possiblc technologies) and the immaturity of the techrologies. The numerous problems betng confronted in the solar demonstration program ${ }^{4,5}$ are difficulties arising from inadequacies of design, materials, installation, user knowledge, etc., some of which will moderate or disappear as the technologies mature and the infrastructures needed become functional. Lack of data, experience, user memory, or "organizational memory" is a serious handicap for assertions of the "benign nature" of solar technologies and of the "free" democralic nature of the resourcc tend to become substitutes for analysis, obscuring the search for issues and impacts, and confusing assumptions with facts. Finally, the usual dilemmas of social impact assessment must be confronled anew in the present context. These include lack of theoretical framework, inadequate methodology, and data gaps. A11 of these problems are compounded by the immature state of most decentralized solar technologies and the shift from a centralized to decentralized framework. In this context, the search for impacts will in some cases be constrained to vaguer "social considerations" until more concrete systems emerge and specific choices can be detailed, and definition of social costs will be delayed likewise. 
In order to reduce the task to more manageable proportions and to remove some uncertainties, the analysis considers primarily the polar cases of centralized electric and decentralized solar residential sys tems.

Preliminary impact criteria and other major "social considerations" categories were developed by (1) reviewing the impact categories used in assessing impacts from centralized electric generation facilities, (2) selecting those which are still applicable to the very different decentralized energy generation systems, and (3) devising new ones to cover significant organizational and structural differences between the centralized and decentralized technologies. The impact criteria thus include:

- resources used (land, air, water, capita1)

- employment effects

- health and safety

impacts found in centralized energy facility assessments

- aesthetics

- perceived risk

- repair and maintenance needs

- user time and participation requirements

- effects on existing centralized systems new categories devised for decentralized technologies

Major additional considerations which appear to be important at this preliminary stage of analysis (at least until more specific information is available about the vast array of possible technologies) include:

- level of impact - individual, group, community, society

- rura1, urban, suburban

- sizing and scaling considerations 
- organizational considerations.

Reviewing the differences between decentralized and centralized technologies reveals the following major considerations which will affect or determine impacts in ways not yet entirely clear:

- functional shifts occur in which first costs and maintenance and repair costs are:borne by user-owners of decentralized solar sys tems.

- the owner-user distinction becomes important'in that separation may retard adoption of individually-owned systems but increase adoption of utility-owned systems. . . :

- sizing and scaling considerations include the possibilities of economies of scale for storage, and easing land use constraints and retrofit problems through intermediate size facilities and/or organizations. Maximizing end-use matching may be more likely at intermediate scales than at the smaljestiscale.

- increased dependence upon climatic cycles and weather uncertainties

- organizational invention and reorganization involves a läge number of choices' and possibilities, including ownership and/or operation by individual, group, cooperative, community or utility leasing arrangements. Hybrid arrangements involving two or more parties in leased or shared systems may offer optimized end-use matching or other advantages. The principal task is invention and integration of the needed infrastructure which will emplace a new technology. 
tradeoffs are numerous and include:

\begin{tabular}{|c|c|}
\hline $\begin{array}{l}\text { citizen control vs. improved end-use } \\
\text { matching } \\
\text { possible optimal conditions for citizen } \\
\text { control }\end{array}$ & $\begin{array}{l}\text { within } \\
\text { decentralized } \\
\text { systems }\end{array}$ \\
\hline $\begin{array}{l}\text { reliability vs. renewability and } \\
\text { decentralization } \\
\text { total self-sufficiency vs. land use } \\
\text { conflict/conversion } \\
\text { first costs vs. continuing costs } \\
\text { export of capital vs. internal } \\
\text { recirculation of capital } \\
\text { perceived risks vs. reliability } \\
\text { and availability of power }\end{array}$ & $\begin{array}{l}\text { between } \\
\text { centralized and } \\
\text { decentralized } \\
\text { systems }\end{array}$ \\
\hline
\end{tabular}

The major impacts identified include:

- land use conversion and conflict resulting from the land use intensive nature of decentralized solar technologies at point of end use. Industrial and biomass uses are most demanding, but residential uses can cause conflicts if the energy system relies totally upon solar or if retrofitting of developed areas is implemented. Other land uses in conflict with solar uses are likely to be in public and recreational lands, unused and urban fringe lands, and agricultural forest lands and products. The least demanding decentralized solar technologies appear to be water heating, passive, biomass wastes and some applications of photovoltaics. 
- employment will increase substantially, changing skill mix and labor supply organization. Up to three times as many total (direct and indirect) workers will be required per quad of energy for hot water and space conditioning as for nuclear energy. Proportionately more skilled workers and fewer white collar or managerial jobs will be required. The fragmented and overlapping organization of the labor supply and its relationship to newly emerging integrated solar skills may cause problems.

- repair and mainteriance demands on users will increase. These demands will be high during the introductory and startup periods of most of the new technologies except passive. Following appropriate shakedown periods, these demands can be expected to moderate. Reduction of repair and maintenance needs depends upon development of infrastructure, increases in installer skills, user knowledge, and possible utilization of organizational inventions such as leasing or maintenance subcontracting. - user time and participation demands will be higher in some cases. Higher repair and maintenance needs and more constrained energy use schedules and availability patterns mean greater user time requirements. Jointly owned, citizen-controlled systems have heavy organization tending and startup requirements. These greater obligatory time requirements infringe on valued discretionary time. Certain groups such as business people, professionals, and working women have very small amounts of 
discretionary time. Organization solutions may reduce these time and participation requirements for small individuallyowned or group-owned systems.

- aesthetic impacts vary from zero to major, depending upon the technology and site specific circumstances.

- health and safety hazards. Many sources of hazard have been identified but the extent and seriousness of these potential impacts has not yet been established.

- perceived risks. from decentralized solar technologies are very low. Solar is generally perceived as benign or even "costless."

The conclusions of the study are that:

- the highest priority tasks for the implementation of decentralized solar technologies are the invention and emplacement of appropriate solar "organization configurations" and their integration with centralized infrastructure.

- further centralization is necessary to implement certain decentralization and integration goals, especially in the areas of federal or state financing; greater coordination, planning and control for land use; and greater coordination and control for load leveling and end-use matching.

- the considerable national benefits include increased employment, decreased reliance on fossil fuels, increased resilience in a pluralistic energy supply system, and reduced capital losses in foreign exchange.

- the greatest impacts are increased land use conversion pressure and conflict. 
- community benefits may include increased cohesion and selfsufficiency if local control is successfully implemented.

- priority technologies with lower levels of impacts include passive solar design, hot water heating, and biomass wastes. 


\section{FOOTNOTES}

1. This summary is excerpted from a larger work: Elizabeth Peelle, Social Considerations Relative to Decentralized Solar Technologies, Oak Ridge National Laboratory, in press, 1980, ORiVL/TM-7335.

2. Bruce Purdy, Elizabeth Peelle, Benson Bronfman and David Bjornstad, A Post Licensing Study of Community Effects at Two Operating Nuclear Power Plants, ORNL/NUREG/TM-22, Oak Ridge National Laboratory, September, 1977.

3. Mark Shields, J. Tadlock Cowan, and David Bjornstad, Socioeconomic Impacts of Nuclear Power Plants: A Paired Comparison of Operating Facilities, ORNL/NUREG/TM-272, JuTy, 1979.

4. James Easterly, "Advice from a Troubleshooter: Engineering Concerns in Solar System Design and Operation," Solar Age 4:(10): 56-61, October, 1979.

5. U. S. Department of Energy, Proceedings of the Department of Energy's Solar Update. Fourth Regional Conference Highlighting the Objectives, Plans, and Experience of the National Commercial Solar Heating and Cooling Demonstration Program and the National Solar Data Program. Conf. No. 780701, July, 1978. 


\section{THIS PAGE}

\section{WAS INTENTIONALLY LEFT BLANK}




\subsection{PROGRAM REVIEW TEAM}

An integral part of the TAP was to involve a small but diverse nroup of professionals who would serve as a Review Team throughout the project. Its role was to encourage those conducting and directing TAP to keep it "interactive in nature" and "policy oriented." As stated in the proposal of The Institute on Man and Science to Oak Ridge National Laboratory dated October, 1978, "The role of the Program Review Team is ultimately one of feedback, suggestion, and advice.... It is seen as a mechanism for providing knowledgeable critiques and commentary on the progress within the program components and even providing suggestions on how to deal with (overcome or alleviate) programmatic or project difficulties. The Team's purpose is to provide constructive but critical comment to the TAP program manager and the project's principal investigators."

The membership of the Team includes a wide range of interests and constituencies including the Department of Energy, the Solar Energy Research Institute, the academic community and private industry. The composition of the Team is flexible and in October. 1979. the Princinal Investigator from the first Community TA in Corning, N.Y., joined the Team. Members as of November, 1979, included:

Private Sector Members

Dr. Alexander Christakis Battelle Memorial Institute

Mr. Douglas R. Boleyn

Portland General Electric

Dr. Gordon Enk

The Institute on Man and Science
Area of Interest

Téchnology Assessment and Energy Futures

Electrical Engineering and Solar Energy Planning

Renewable Resource Economics and Technology Assessment of Solar Energy 
Dr. Paut Friesema

Northwestern University

Dr. Roy Rappaport

University of Michigan

Ronald Stewart

State University of New York Albany

Clara Miller (added October, 1979) Private Consultant, New York, N.Y.

\section{Public Sector Members}

Dr. Benson H. Bronfman

Oak Ridge National Laboratory

Dr. Eugene Frankel

Department of Energy

C. Harvey Major

Department of Energy

Rohert. ndland

Snlar Energy Research Institute

Dr. Sam A. Carnes

Oak Ridge National Laboratory
Politics of energy and community level decision making

Anthropology and

societal energy decisions

Atmospheric Sciences

and Solar Technology

Planner and P.I. from

first Community TA

Political Scientist, Leader

Social Impact Analysis Group

Historian of Science

and Developer of Community

TAP for DOE

Economist, Office of Policy, Planning and Evaluation

Lawyer, Planner and analyst of land use impacts of solar. energy

Political Scientist and Program Manager (from December, 1979) 
Detailed summaries of the Review Team meetings have been submitted by the project administrator to the DOE program manager, the ORNL project director, Review Team members, and TAP project directors and project staff who have participated in Review Team meetings. A brief summary of the key conclusions and recommendations that resulted from these meetings provides a sense of the deliberations and recommendations.

\subsection{First Meeting - December 6-8, 1978 - Rensselaerville, N.Y.}

A key focus of this meeting was to provide Review Team members with an understanding of the program, gain their commitment, and examine the progress of the four projects composing the Scenario Development Task. These four projects were directed by principal investigators from the University of Massachusetts, Amherst, Massachusetts; The Institute for Local Self Reliance, Washington, D.C.; State University of New York at Stony Brook; and the American Institute of Architecture-Research Corporation Washington, D.C. Following the review and progress assessment, the Review Team concluded that the scenario development of the University of Massachusetts team "appears to be noteworthy and encouraging." The Team recommended that the ORNL Project Director explore the possibility of expanding the University of Massachusetts Team's work into the development of a Community-Level Technology Assessment. No product was presented by Stony Brook, but its potential importance was noted by the Team.

The Review Team further concluded that the Technology Assessment Program description and the supporting documents failed to present a 
clear image or understanding of what was being undertaken and what expectations were held for each project component. It highly recommended that the ORNL Project Director take whatever steps were necessary to rectify this situation and improve everyone's ability to communicate about the program, its goal, processes, components, expected results, and desired impacts.

The Review Team recommended that a new task bc added to the Program. This task should focus on "the evaluation of the process and product of the community-level technology assessment projects." They recommended that this task be:

- DOE funded

- University based

- Independent (i,e., outside the current program)

The Review Team recommended that specific consideration be given as to how to directly link the work of the support studies into the work of the community-level task teams. Members of the Review Team agreed that the linkages of the parts to the whole needed to be strengthened. A serious question was asked as to the expected utility of the background studies (scenario development tasks).

The Review Team concluded that there was a need to examine and understand the role of the Request for Proposal in the stimulation of Community-Level Technology Assessment (especially Richmond, Kentucky and Kent, Ohio. This was undertaken as a responsibility of Dr. Paul Friesema who requested no additional funds, only access to information about the responses to the RFP once they were received. The study has not been completed. 
The Team offered several suggestions regarding the definition of the Technology Assessment Program. These were summarized by Dr. Roy Rappaport when he stated:

"-This is not an experiment;

-We are starting a process;

-We are intervening;

- There are some principles involved;

-We are attempting to induce and enhance the selfcorrecting capacities of the system;

-We are trying to stimulate understanding."

It was concluded that the Review Team itself might emerge as a key component of the Technology Assessment Program. The Team's meeting provided the opportunity for all of the TAP components and principals to come together periodically to build a sense of community and a learning system.

It was strongly suggested that the DOE Program Manager and his superior should be an integral part of the TAP Review Team meetings, if at all possible.

\subsection{Second Meeting - March 1-3, 1979 - Washington, D.C.}

Meeting 2 was heid in Washingtun, D.C. In addition to the TAP Review Team members, invited guests included the Principals in the Southern Tier Central Community-Level TA and the Program Manager for the RFP distributed by Argonne National Laboratory.

The Review Team concluded that the work-to-date of three of the four principals on the Scenario Development Task had definitely been below expectations. There was a need to improve the understanding of both the commitment and the timetable for products to come out of the principals from State University of New York at Stony Brook (no product 
received), the Institute for Local Self-Reliance and the American Institute of Architecture-Research Corporation.

Upon review of the Community-Level Technology Assessment work of the Southern Tier Central Regional Planning and Development Board (Corning, N.Y.), it was strongly suggested that the project consider adding a historian or an ethnographer to the staff. This person wnuld rerord what was happening and the results of the interactions between the professional staff of the Regional Planning and Development Board and the citizens in the communities. It was pointed out that this role was distinct from evaluation.

The Review Team reviewed the interim products of the Corning project (The Energy TA Workbook, Renewable Energy Technology Handbook, and Renewable Energy Resource Inventory), at the request of the Southern Tier staff. They were also explicitly asked to review the Interim Report of The Institute for Local Self-Reliance. Both tasks were completed through individual memos from members of the TAP Review Team to the principals involved.

The Review Team reiterated its call for a concise and readable description of the TAP that could be used both for internal understanding and outreach efforts on the program, its activities, goals, purposes, expected results, and progress to date. It noted that there was still a great deal of ambiguity as to the program's goals, intent, and future expectations. It was suggested that the Program Manager (DOE) and Project Director (ORNL) explicitly consider adding an activity that would clarify the answers to these questions. 
8.3 Third Meeting - July 17-20, 1979 - Rensselaerville, N.Y.

Participants in Meeting 3 included the Review Team members, principals from the Franklin County Study, Southern Tier Central Community TA, Kent, Ohio, Community TA, Richmond, Ky., Commmunity TA, and Dr. Rashid Ahmad of Battelle-Columbus Laboratories, who presented a White Paper describing the conceptual framework, goals, and purposes of the entire TAP.

The meeting provided an opportunity for the increasing number of principals in the TAP to come together to encourage mutual learning and understanding of the goals and purpose of the overall TAP.

The Review Team called for stronger measures to ensure that the products from the Scenario Development Task be developed, reviewed, and disseminated. The deadline date for this was September, 1979. Team members expressed a strong concern that a quality product be developed focusing on the role of solar energy in the suburban environment. No product had been received from Stony Brook. The Review Team called for the DOE Program Manager to intercede with NEA or the grantees themselves to insure delivery of the products.

The Team gained a first-hand understanding of the design, tasks, approaches and goals of the Richmond, Kentucky, and Kent, Ohio, Community TA's, which had been awarded contracts based on the Review of Proposals submitted to Oak Ridge National Lab and Argonne National Lab under the RFP process. The Principal Investigators from the Richmond and Kent projects gained first-hand acquaintance with the Review Team and other project principals. They learned that talents and abilities were available to assist them as they initiated and conducted the TA's. 
The Team reviewed the draft of the Oak Ridge National Lab supporting study on the "Barriers to Solar Energy" and recommended that the study include an examination of the political, institutional and-regulatory aspects of solar. A clearer identification of the exact audience for this report (e.g., was it being written for members of town boards, environmental councils, city planners, state-level decision makers, or federal agency representatives) was also requested.

The Team reviewed the outline of the paper on the Social Costs Task by Oak Ridge National Lab. It raised questions regarding the direction (e.g., "this is more of a scholarly paper") of the study and stated that it was unclear as to how this paper would contribute to the development of a Community-level Technology Assessment Program. The Team strongly recommended that the ORNL Project Director and the Principal Investigator consider this question in more detail. Later drafts of the Social Costs paper appear to have answered these initial concerns.

After a presentation by the Franklin County Scenario Development Team, the Program Review Team considered additional funding for them to expand their work to a community level TA. It was pointed out that the "letter of interest" from the Principal Investigators lead to serious questions as to whether they were requesting support of a Community-Level TA or the funding of a new institution that might not lead to achievement of goals and purposes of the TAP. Upon receipt of an acceptable proposal, ORNL added Franklin County as a fourth community level TA.

The Review Team noted that it was delighted with the work to date of the Southern Tier Community-Level Technology Assessment. It considered the steps to initiate an implementation program that had 
been undertaken by the principal investigator. It reiterated the need, however, for the Principal Investigator to be given the resources to examine the policy implications and lessons learned from the first community-level TA. It recommended that the Review Team be strengthened by adding the Principal Investigator of the Corning study to its membership.

The Team reviewed, discussed and critiqued the report on the framework for the technology assessment program as developed by Rashid Ahmad, who had been commissioned by the DOE Program Manager and the ORNL Project Director to undertake the development of a ciear and concise paper that would describe the program to both outsiders and those working within the TAP. The draft of "Community Based Technology Assessment - A META iriodel," "July i979, was reviewed and this led to the detailed comments and recommendations to the author. This document is avaiiabie as a working draft.

The Team reviewed the progress and interim report of the staff of The Institute on Man and Science regarding the June, 1979, workshop on the Social Impacts of Decentraiized Energy Systems. They recommended thiat the interpretive Summary be pubijished as soon as possible for wide dissemination and that the hardbound book, based on presented formai papers, be reviewed and pubijshed if possible. The summary nas not been published due to a lack of sufficient funding. Discussions with DOE regarding this possibility are under way.

8.4 Fourth Meeting - November T-9, 1979 - Rensselaerville, N.Y.

The meeting opened with a brief report by Ben Bronfman concerning the status of the Technology Assessment Program. The agenda was 
modified to allow considerable time for reconsideration of the activities and directions of the TAP in the next year. It was decided to address the issues at the opening of the Friday session.

Gordon Enk informed the Review Team that the DOE program Manager had submitted four questions on Wednesday $(11 / 7 / 79)$ which the Team was asked to consider if time permitted. They are the following:

1. Where have we really come? Haye we learned anything conceptually from the Program? Has anything important been learned? What is nf valıp?

2. What recommendation does the Team have regarding future work on the question of Institutional Barriers? If further work is indicated, should it stress the question of implementation or planning? Should we do case studies or more generic work?

3. What kinds of questions are we raising that could not be answered in the first year that should be addressed in vear two?

4. Where should we be heading?

The Review Team felt that these questions were in keeping with the items to be discussed on Friday marning. Further, since the agenda had proposed to focus on the work of Schweitzer and Peelle, Thursday should be devoted to considering their work. Ben Bronfman requested the Review Team to add a fifth question to the list:

5. What should we do with the publications prepared to date as part of the TAP? What should be our strategy for outreach?

Bronfman informed the Team that he and his staff were also working on a Review of Program Activities Report to be submitted to the Department of Energy. He noted that Gordon Enk would be contributing a brief description on the work of the Review Team.

At this time, the Review Team members received several papers which were "working documents" for the meeting. These included: 
Energy and Social Change: A Historical Perspective, authored by Eugene Frankel;

Social Considerations Relative to the Impacts of Decentralized Solar Technologies, authored by Elizabeth Peelle, dated November 6, 1979;

Slide presentation on Social Considerations Relative to Decentralized Solar Technologies, by Elizabeth Peelle, dated November 8, 1979;

Franklin County Energy Study: A Renewable Energy Future, by David Pomerantz, et al.

Baltimore: Solar and Conservation Potential by the Year 2000, by James Sullivan, et al.

Value Issues in Technology Assessment, authored by William F. Hornick \& Gordon A. Enk, final copy;

Interim Report on the Work of the Program Review Team (draft for comment), dated November 1, 1979, drafted by Gordon A. Enk;

Observations on the Decentralized Solar TA Program Support Studies; authored by Gene Franke1, dated November 7, 1979.

In accordance with the agenda, the Team received a presentation by Marty Schweitzer concerning his report on the Legal and Institutional Issues in the Use of Decentralized Solar Energy Systems. Schweitzer pointed out that the report was written with five audiences in mind:

1. Solar TA Communities

2. Local planners

3. State and federal policy makers

4. Utility and solar industry

5. Potential solar users.

He stressed that he sought to identify problems and was looking for areas in which solutions could be suggested as well as pointing out the appropriate level of response. He had restricted himself to direct solar technologies with an emphasis on residential and commercial applications. There was an explicit exclusion of cogeneration and industrial users. He pointed out that he had focused on the formal literature and areas in which legislative proposals had been presented or enacted. Since the Review Team had previously reviewed the draft of Schweitzer's paper, the Team entered into discussion and dialogue with him. 
Based on the discussions, it was recommended that the next steps be more community and experientially oriented. Schweitzer should develop actual contact with communities dealing with the development of community-level solar energy programs and examine their responses to legal and institutional barriers. This additional work has not heen funded.

The Review Team then received copies of Elizabeth Peelle's paper, "Social Considerations Relative to Impacts of Decentralized Solar Technologies," dated November 6, 1979. One and a half hours were a?? nwed for individual review of the paper. This was followed by a presentation by Peelle:

Peelle presented five questions for the Review Team to consider as she discussed her work:

1. Was the direction she had embarked on useful and fruitful?

2. Would changes in her basic assumptions improve her study?

3. How should the work be relatcd and dovetailed with other work in the TAP, communitics' $T \Lambda^{\prime} s$ and the values work?

4. What audicnccs would most understand social costs related to decentralized solar technologies? Should there be separate studies, for example, for solar users, industry, government agencies, etc.?

5. What was missing from the work as proposed to date?

The Review Team strongly endorsed the manner and style in which Peelle was approaching her research task. They strongly recommended that she be encouraged to pursue her work as quickly as possible. This additional work has not been supported within the TAP.

Based on the Team's earlier decision, the second day of the meeting opened with the discussion on the future directions of the TÁP. Discussion was initiated by Gene Frankel's request that the Team consider his :Observation Paper,:" in which he stressed that the TAP had made a shift toward pianning and implementation and awav from ascescment. 
Paul Friesema and Aleco Christakis feit that the Team needed to clarify what the TAP was actually doing and why the shift in emphasis had taken place.

It was agreed that while the four questions presented by Mary Glass were timely, it was basicaliy impossible to answer them, "off-the-cuff," with an hour or two of discussion. The Team felt that a more structured and thoughtful approach should be developed in which the Review Team could quickiy arrive at answers to Mary Giass's questions. Aleco Chiristakis proposed that this be done as part of this Progress Report. A general outline was agreed to by the Review Team.

After much discussion among the PRT, and DOE, it was decided to schedule a "fuli" Review Team Meeting in February, 1980, where the central focus would be the questions posed by $\tilde{O} O E$ and augmented by ORNL and Gorcion Enk.

Beri Bronfilian requested the Review Team's comments on the repurts presented by Franklin County and the Baltimore Report from The Institute for Local Self-Reliance. He requested that the Review Team make recormendations as to whether the reports should be widely disseminated. The Team recommended that, after correction of the minor data errors, it be released for wide dissemination. The Baitimore study should be distributed to 20-50 individuals working in the field for their review andi evaluation. It shouid not be widely disseminated at this time.

At Gordoin Enk's request, the Team was asked to make a recommendation concerning the widespread dissemination of The institute's Values paper. After discussion, it was decided that this issue should be dealt with 
by the Review Team at the next meeting since they needed time to review the final copy which they had just received.

Ben Bronfman also asked the Review Tearn to review the request of The Institute on Man and Science for additionai funds for continuing $i$ ts work toward compietion of $i$ is efforts on the Decentralization Workshop and the release of its Finai Report. The Team strongly recommended that The Institute on Man and Science be given additionai funds from the Depariment of Energy to complete its work on the Decentraization Workshop and the other tasks invoived in its contract. (Gordon Enk excluded himself from the discussions and decision concerning the Values Paper and additionai funds.) 


\section{FOOTNOTES}

1. Rashid Ahmad, "Community-Based Technology Assessment -- A Meta-Model," Battelle Columbus Laboratories Washington Operations, Washington, D.C., July, 1979 (mimeo). 
THIS PAGE

\section{WAS INTENTIONALLY LEFT BLANK}




\subsection{GENERAL SUPPORT}

Tile Drimary jurūose of the general management task of the TAP was for provision of management, coordination, and support for the overall program. This task, as evolved in discussions with DOE, involved not only planning, coordination, and contract management of ORNL tasks, but also support to the DOE program manager in several areas.

1. Coordination of DOE/NEA "Background Studies," funded in FY 1978, prior to ORNL's involvement in the TAP. Of the four grants awarded by NEA ${ }^{\top}$, three -- the Franklin County Energy Study, the Baltimore Study and the SUNY Suburban Scenario -- have been completed. $^{2}$ The AIA Research Corporation does not have a product as of this date.

2. Special Studies -- In consultation with the DOE project manager, ORNL initiated contracts for three special studies during $F Y$ 1979.

a. Community Based Technoloqy Assessment: A Meta-Mode 1 This study was undertaken by Dr. Rashid Ahmad of BattelleColumbus Laboratory, Washington Operations. 3 The major purpose was to review all prior TAP documents and relevant literature for the purpose of providing a common, shared understanding of the theoretical underpinnings of the TAP. The paper, completed in july, 1979, has been distributed to members of the Review Team and the four communitv projects. Amona its conclusions was that the approach used in the TAP has value beyond the program, that it may enable 
different constituencies more effectively to communicate with each other, and that it can be used as an evaluation tool for other assessments.

b. County Energy Planning Handbook

Support has been given to the completion of the county Energy Planning ïanabook, ${ }^{4}$ published by the Center for Ecoiogical Policies. ORNL's support has been directed at pretesting of the handbook, a survey of users, and a finai revision and pubicaton. As a resuit of the pretest and survey, revisions on a chapter on community organization were made, the preface was rewritien to ei iminate what were thought to be biases, 1979 data on energy consumpion were updated to 1977, and charges in the methodology were made to reflect the new data. Additionally several "networking" appendices were added, and some minor editorial and grapinics revisions were made. This effort, at blut's request, was hegun in August, iy/y, for a perlod of four munlhs: Cujies of the initial handbook have been made available to the four community TÅ projects.

6. Empioyment Impartis nít Riomass

At. the request. of $D O E$. funding was provided to the Manpower Empioyment Kesearch Team of the Oak Ridge Assuciaied universities to undertake a case study of employment in biomass in New England. ${ }^{5}$ After discussions with ORNL, it was decided that the case studies would be selected from biomass industries in Franklin County, Massacnusetts, and the Southern Tier of New York. Prei iminary results indicated 
thiat capital and labor costs for construction of methane generators varied considerably and that the feasibility of decentralized methane gas production appears to be dependent upon capita i aná construction costs. Further, it was sirown that using waste wood residuals or wood chips as boiler fuel in electric utilities and physical piani facilities can be economically viable in areas near abundant forest lands and can create new employment opportunities in, the wood chipping and forest development areas. 


\section{FOOTNOTES}

1. See chapter 1 , Tables 1 and 2 .

2. Frankl in County Energy Study: A Renewable Energy Scenario for for the Future, Futures Studies Program, University of Massachusetts, Amherst, MA, Apr11, 1979; J. Sullivan, R. Cornman and D. Morris, Baltimore: Solar and Conservation Potential by the Year 2000, Institute for Local Self Reliance, Washington, D.C., October, 1979 (Draft); T. 0. Carroll and R. Nathan, Solar In Suburbia: A Case Study on Long Island, Institute for Energy Research, State University of New York at Stony Brook, November, 1979 (Draft).

3. R. Ahmad, "Community -Based Technology Assessment -- a Meta-model," Batte 1 le Columbus Laboratories Washington Operations, Washinytun, D.C., July, 1979 (mimeo).

4. A. Okagaki and J. Delison, Coulity [inerav Fianning llandhank. Centern for Ecological Policies, Fairfax, Va., 1979.

5. L. M. Blair, J. Craven and W. Stevenson, Community Level Employment and Income Impacts of Biomass Energy Development and Use: A Pilot Case Study, Manpower Research Programs, Oak Ridge Associated Universities, Oak. Ridge, Tennessee, Or.tober, 1979 (Draft), 
ORNL/TM-7189

INTERNAL DISTRIBUTION

1. H. G. Arnold

2. S. I. Auerbach

3. S. E. Beall

4. L. G. Berry

5. F. D. Boercker

6. C. R. Boston

7. R. B. Braid

8-12. B. H. Bronfman

13. L. M. Bronfman

14. A. A. Brooks

15. R. L. Burgess

16. R. S. Carismith

17-21. S. A. Carnes

22. C. V. Chester

23. E. D. Copenhaver

24. R. M. Davis

25. J. E. Dobson

26. W. Fulkerson

27. D. L. Greene

28. E. Hirst

29. R. B. Honea

30. D. Jared

31. G. E. Kamp

32. S. I. Kaplan

33. M. Karnitz

34. S. V. Kaye

35. J. M. Klopatek

36. E. G. Llewellyn

37. A. S. Luebl
38. F. C. Mainschein

39. H. A. McLain

40. J. W. Michel

41. W. R. Mixon

42. J. C. Moyers

43. D. C. Parzyck

44-48. E. Peelle

49. G. Pine

50. H. Postma

51. C. R. Richmond

52. M. W. Rosenthal

53. T. H. Row

54. G. Samueis

55-59. M. Schweitzer

60. J. W. Sims

61. J. Tatum

62. D. J. Wilkes

63. T. J. Wilbanks

64. H. E. Zittel

65-66. Central Research Library

67. Document Reference Section

68-72. Laboratory Records

73. Laboratory Records (RC)

74. ORNL Patent Office

75-215. Social Impacts Group of the Regionail and Urban Studies Section, Energy Division

\section{EXTERNAL DISTRIBUTION}

216. Office of Assistant Manager, Energy Research and Development, DOE-ORO

217-243. Technical Information Center, DOE

244. Douglas R. Boleyn, Portland General Electric, 121 S.W. Salmon Street, Portland, OR 97204

245. Alexander Christakis, Department of Electrical Engineering and Applied Science, University of Virginia, Charlottesville, VA 22901

246. Mark Christianson, Energy \& Resources Program, Room 100, B1d. T-4 University of California Berkeley, Berkeley, CA 94720 
247-251. Gordon A. Enk, Director of Economic and Environmental Studies, The Institute on Man and Science, Rensselaerville, NY 12147

252. Eugene Frankel, House Science and Technology Committee, B-374, Rayburn Office Building, Washington, D.C. 20515

253. Paul Friesema, Center for Urban affairs, Northwestern University, 2040 Sheridan Ave., Evanston, IL 60201

254. C. Harvey Major, Department of Energy/CS, Room 2220, 20 Massachusetts Ave., N.W., Washington, D.C. 20545

255. Bennet Miller, Director, Office of Solar Energy, MS-404, 600 E Street, N.W., Washington, D.C. 20585

256. Clara Miller, 171 E. 90th Street; New York, NY 10028

257. Robert Odland, Solar Energy Research Institute, 1536 Cole Bivd., Golden, C0 80401

258. John Ostrowski, Kent Solar Project, 319 S. Water Street, Kent, Ohiu 44240

259. Janet Patton, Department of Political Science, Eastern Kentucky University, Richmond, Kentucky 40475

260. David Pomerantz, Northeast Appropriate Technology Network, Inc., P. 0. Box 548, Greenfield, Massachusetts 01302

261. James Quinn, Office of Solar Energy, Division of Planning Analysis, MS-404, $600 \mathrm{E}$ Street, N.W., Washington, D.C. 20585

262. Roy Rappaport, Department of Anthropology, University of Michigan, Ann Arbor, MI 48104

263. Jesse Rushing, DOE-ORO

264. Kenneth Smeltzer, Argonne National Laboratory, 9700 South Cass Avenue, Argonne, Illinois 60439

265. Ronald Stewart, Atmospheric Science Research Center, State University of New York at Albany, Albany, NY 12222

266. Steve Weisman, Southern ijer Central Regional Planning and Develupmenl Budrd, 53 1/2 Bridye Slreel, Corniny, NY 14830

267-317. Mary W. Glass, Office of Solar Energy, Division of Planning Analysis, MS-404, 600 E Street, N.W., Washington, D.C. 20585 